\title{
A Methodological
}

Framework

to Assess

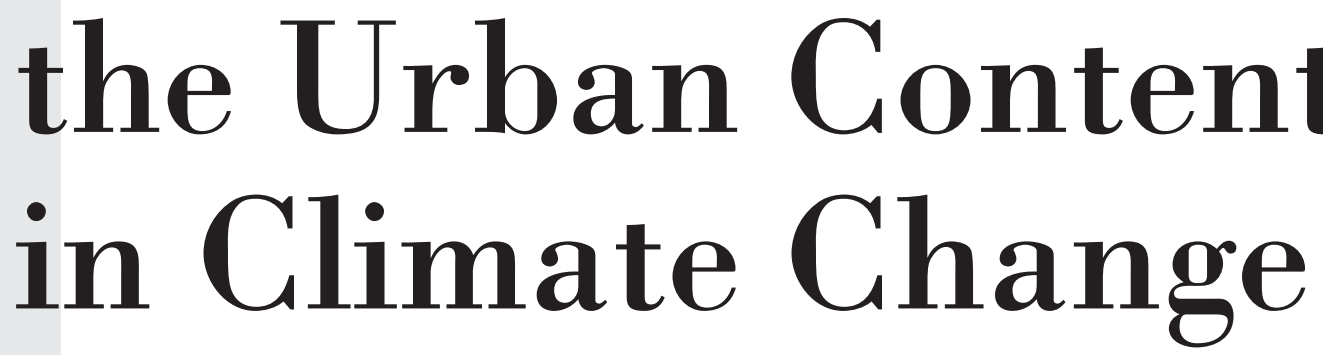

Policies

Maria Pizzorni*, Ombretta Caldarice**, Nicola Tollin*** key words: global south, climate change policies,

National Adaptation Plan (NAP), nationally Netermined Contributions (NDCs), spatial planning,

Brazil

\section{Abstract}

By 2050, people in urbanized areas will account for $68 \%$ of the world's population, $80 \%$ of which will be concentrated in Asia and Africa. The United Nations Framework Convention on Climate Change (UNFCCC) introduced in 2011 the National Adaptation Plan (NAP) under the Cancun Adaptation Framework (CAF). Countries of the non-Annex I, described by the UNGeneral Assembly as especially vulnerable to the impacts of climate change, are invited to develop NAPs to identify adaptation challenges and devise appropriate climate adaptation responses. Recognizing the increasing vulnerability of urban systems to the effects of climate change, in 2019, UN-Habitat defined the supplement of the NAP process's technical guidelines for addressing urban and human settlement issues in NAPs. This paper aims to propose a methodology to assess the urban content of the NAPs after ten years from that the CAF comes into force. The evaluation is based, adapting and expanding, on the methodology used to assess the urban content of Nationally Determined Contributions (NDC) published by UN-Habitat in 2017. The methodology aims to analyse both key adaptation challenges and responses explicitly or implicitly related to urban systems.
Moreover, it aims at understanding the interlinkage of urban content in NAP in relation to other key policies, such as NDCs and National Urban Policies (NUPs). In this perspective, 172 indicators were selected and clustered into nine groups: (i) Geographic Indicators; (ii) General Indicators; (iii) NAPs General Indicators; (iv) NAPs Urban Indicators; (v) NDCs Indicators; (vi) NUPS Indicators; (vii) Urban content in National Policies Indicators; (viii) International policy linkages (including SDGs, Sendai Framework for Disaster Risk Reduction, Paris Agreement and New Urban agenda); (ix) National plans/policy/strategies/reports linkages. The methodology was tested on Brazil's NAP, trying to find general considerations to apply to the countries that officially submitted their NAPs between 2014 to 2020. The test showed that: there is a stronger focus on defining climate adaptation challenges more than responses; climate adaptation challenges and responses are predominantly identified at the national scale, with a focus on policies and strategies at the national level; among the Brazilian NAP, there is "cities strategy", and it means that the NAP has a high urban content. In conclusion, the paper will highlight critical issues and improvements for each of the nine indices analysed. 


\section{INTRODUCTION. TOWARDS MAINSTREAMING ADAPTATION TO CLIMATE CHANGE AT THE LOCAL LEVEL}

We live in an urbanizing world: today, $55 \%$ of the world population live in cities ${ }^{1}$, which occupy only $3 \%$ of world land, consuming $75 \%$ of global energy, producing $80 \%$ of Greenhouse gas emission and $80 \%$ of the Gross Domestic Product (Fee et al., 2019; Williams, 2007). Rapid urbanization, uncontrolled migration, resource depletion, and climate change impacts will affect most developing countries, including non-Annex I countries, following the classification of UNFCCC identified by the UNFCCC as belonging to non-Annex I, including mostly developing countries (UNFCCC, 1992). By 2050, 80\% of the world's urban population is expected to be concentrated in Asia and Africa (Plescia-Boyd et al., 2020). These regions are challenged by poverty, informal settlement, lack of infrastructure, and essential services provided and, therefore, less prepared to deal with climate change. (Carmin et al., 2012; Datta and Shaban, 2016; Evans, 2011). The absence of certain services and infrastructures compromises their ability to respond quickly and effectively to the challenges imposed by climate change: coastal settlements are displaced, and rising seas contaminate inland freshwater, compromising crop yields and agricultural production (Romero Lankao and Qin, 2011).

In addition to rapid growth, urban systems are also exposed to other factors such as natural disasters, economic crises, and political changes, problems that contribute to complex urban systems (Fee et al., 2019; Hallegatte and Corfee-Morlot, 2011; Meerow et al., 2016). The effects of climate change, beyond its negative impact on cities, have also a multiplying effect on the other urban challenges, making cities more vulnerable. Urban areas contribute to climate change and at the same time suffer from its effects, becoming both victims and culprits of climate change (Carmin et al., 2012; Matthews, 2011). Urban and human settlement are drivers of economic prosperity, hubs of governance and institutions, encounters of cultures, ideas, and science, but they are also drivers of climate change. Integrating urban issues in local actions is imperative for addressing urban challenges, decreasing vulnerability, and improving urban systems' adaptive capacity (Fee et al., 2019).

In this view, the link between rapid urbanization, economic development, and climate change effects can

\footnotetext{
${ }^{1}$ Urban systems are defined by Meerow et al. (2016) as "complex and adaptive, and it is composed of socio-ecological and sociotechnical networks that extend across multiple spatial scales". Moreover, the 2018 Cities IPCC Research and Action Agenda outlines that cities are "open, complex, self-organizing, adaptive, and evolving formations that are embedded in broader social, ecological, economic, technical, institutional, and governance structures" (Prieur-Richard et al., 2018, p. 3).
}

be found in transformative adaptation (Brunetta and Caldarice, 2020). As described by IPCC (2018, p.55), transformative adaptation "changes the fundamental attributes of a socio-ecological system in anticipation of climate change and its impacts". More on this point, the Coalition for Urban Transitions Report (2019) stresses that cities can and shall be significant catalysts of change in implementing actions for climate adaptation and mitigation in the face of multiple concurrent crises. Therefore, adaptation is needed to make current and future settlements resilient to the effects of climate change

As outlined by Olazabal and Ruiz De Gopegui (2021), adaptation in large cities is unlike to be effective: the authors analysed 59 cities, identified across a set of 136 coastal cities of over 1 million inhabitants located in developed and developing world regions, assessing the progress, effectiveness and sustainability of public adaptation policies. The analysis concluded that large cities adaptation planning is ineffective due to insufficient vulnerability reduction, failure to increase resilience, and short-term adaptation at the urban scale. The authors believe that to overcome adaptation limits at the urban scale, adaptation needs to be integrated into institutional frameworks to ensure the presence and effectiveness of long-term adaptation actions. Several other authors have defined some barriers to adaptation (Berrang-Ford et al., 2014; Harman et al., 2015; Masson et al., 2014; Meerow and Newell, 2019; Simon, 2014). The lack of institutional and governance capacity increases the difficulty of developing and implementing climate change adaptation strategies, undermining global adaptation progress (Berrang-Ford et al., 2011, 2014). The lack of data and indicators for quantifying adaptation makes it difficult to assess the effectiveness and results of adaptation, which is also reflected in insufficiently mature monitoring and evaluation systems that do not support governments decision-making (Berrang-Ford et al., 2011; Olazabal and Ruiz De Gopegui, 2021). Furthermore, Countries are facing clear challenges in accessing financial resources, technology and in strengthening institutional capacity, despite all initiatives established under the umbrella of the Paris Agreement Finally, the lack of a multi-scalar approach to adaptation limit the effective harmonization and alignment of policies at the national with actions at sub-national, and specifically at urban level. It is difficult for national administrations and institutions to identify adaptation challenges and responses effective at the local scale (Aylett, 2015; Meerow and Newell, 2019; Romero Lankao and Qin, 2011).

To make adaptation to climate change effective is necessary to enhance the support and built capacity for evidence-based policymaking, to translate policies into actions, particularly at the local scale, and to strength the inclusion of the human settlement issues in national policies, in perspective to reduce people vulnerabilities and to improve adaptabilities to climate change (Fee et al., 


\section{A Methodological Framework to Assess the Urban Content in Climate Change Policies}

2019). Furthermore, it is believed that the challenges imposed by climate change must become systematic priorities in the planning process at the local scale, in order to transform challenges into adaptation actions in a mainstreaming perspective (Brunetta et al., 2019). However, adaptation process, especially since the 2000s, is increasingly accompanied by international policies under the UNFCCC. In particular, National Adaptation Plan (NAP) process was established by the United Nations Framework Convention on Climate Change (UNFCCC) under the Cancun Adaptation Framework (CAF) in 2011. These plans' primary goal is to build adaptive capacity to reduce vulnerability to climate change through mainstreaming adaptation. Recognizing the role of cities in coping with climate change, UN-Habitat published in the 2019 Guidelines for addressing urban content in NAPs (Fee et al., 2019), which recommends the identification of challenges imposed by climate change and the definition of adaptation measures at the urban scale.

A review of the urban content of the first submission of the NDCs was already performed, showing that countries were highlighting consistently general climate change challenges, and that countries with urban content were also having a strong focus on climate adaptation, although actual climate adaptation measures were scarce. Moreover, the analysis shows that transition and developing countries are having higher urban content than developed ones. These results are supporting the need for an integrated analysis of the urban content of both NDCs and NAPs, highlighting the presence or absence of explicit challenges and measures on climate adaptation at sub/national level. Moreover, a review on the status and implementation of NUPs (National Urban Policies), not regarding urban content, was prepared in 2018 by OECD in collaboration with UN-Habitat. The two organizations have co-led the Global State of National Urban Policy Report (OECD, 2018) to monitor NUP elaboration worldwide, including 150 countries out of 193 UN Member States.

In light of the many pressures experienced by urban systems (climatic and non-climatic), the fundamental role of local action in addressing climate change, and the direction taken by policies towards reducing the vulnerabilities of urban systems, this paper will analyse the urban issue concerning climate change in adaptation policies. The paper presents the methodology designed to develop a preliminary assessment of National Adaptation Plans' urban content (NAPs). After this introduction, the methodology is presented in section 2. Considering 172 indicators, the countries that submitted the NAPs are described from a geophysical, demographic and economic perspective. In section 3, the methodology is tested analysing Brazils' NAP. and the main results of the analysis s are presented. In section 4, conclusions and a list of improvements for the assessment methodology are presented, together with future research work.

\section{THE NAPA METHODOLOGY. A FRAMEWORK TO ASSESS URBAN CONTENT IN CLIMATE CHANGE ADAPTATION POLICIES}

The purpose of urban content research in climate change adaptation policies is to strengthen the explicit inclusion of urban challenges and responses for cities within national planning processes. This research should support evidence-based policymaking to promote more effective climate change adaptation policies and actions, mainly through multi-level governance. Therefore, highlighting the current shortcomings in implementing urban content in adaptive climate change policies should be the starting point for the definition of new guidelines to strengthen urban content in (inter)national policies and address the gap in the shift from national policies to local actions.

Searching for the urban content means identifying policy references to climate change adaptation challenges and adaptation responses, first in general terms and then with reference to urban systems (Fig. 1). Challenges and responses may include sectorial issues/approaches, such as: coastal protection works, processes, such as reducing settlement in flood zones, financing, both in terms of availability and distribution of financial resources, and others. These challenges and responses may be identified at the national or local level and may have policy, strategic, or action content ${ }^{2}$. Moreover, challenges and responses have been identified first generically, in macro sectors (adaptation, mitigation, institutional capacity, technology, and finance), and then in specific sectors (e.g., water management, infrastructure, food security, etc.). This research allows us to identify the macro sectors that are most vulnerable due to challenges and the most proactive, due to responses, concerning adaptation to climate change. The research continues with evaluating and comparing urban content in three climate policies containing the urban content (NAP, NDCs and NUP). Finally, the research intends to look for climate-related policies, strategies, and plans mentioned in each NAP, analysis that allows highlighting the relationship between urban content and climate change in the different national references.

The methodology used for the NAPs is derived from the methodology already used for reviewing the urban content of Nationally Determined Contributions (NDCs) developed by Tollin et al. (2017). The NDCs methodology

\footnotetext{
${ }^{2}$ Policy content refers to those challenges or responses that are guiding principles provided and approved by a government that has force of low and that helps institutions and organization make decisions; moreover, policies can be legislative (national level) or regulatory (local level). Strategies are defined as sectoral guidelines to reach goals and objectives defined by the policies and a tool to define priorities. Actions offer specific indications that lead to the implementation of policies and strategies, defining timing, financial support and physical developments.
} 


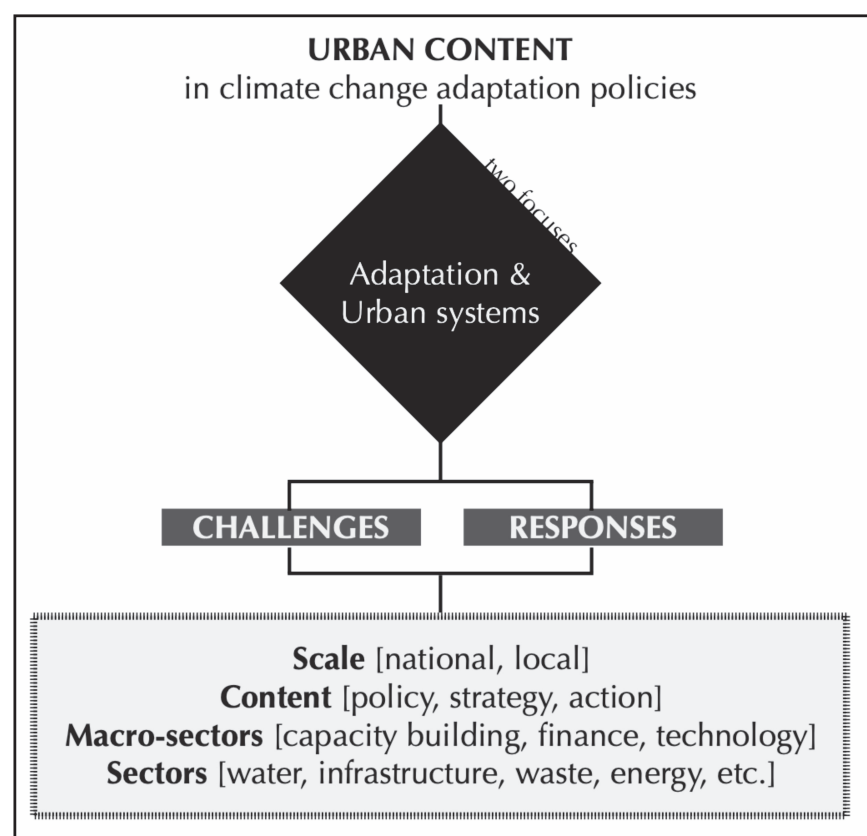

Figure 1 - Searching for urban content in climate change adaptation policies: challenges and responses.

was structured on a matrix of indicators, filled for 160 countries, adapted and expanded to match the characteristic of NAPs, and further developed to including some needs for improvement already identified during the analysis content of the NDCs. The NDCs methodology has been conducted on 160 NDCs submitted before August 2016 from 188 states (Europe is considered a unique part of the analysis). The NDCs are submitted every five years defining how countries are contributing to achieving the goals set within the Paris Agreement ${ }^{3}$.

The methodology objects are NAPs, non-binding national climate policy addressed to states belonging to the nonAnnex I group defined by UNFCCC (1992). NAPs can be adapted to all national context due to their flexibility and their four common elements and process phases: (A) Laying the groundwork and addressing the gaps; (B) Preparatory elements; (C) Implementation strategies; (D) Reporting, monitoring and reviewing (UNFCCC, 2012). Only 20 NAPs have already been submitted to UNFCCC between 2014 to 2020 .

${ }^{3}$ UNFCCC, in February 2021, analyzed 48 NDCs, representing 75 Parties, submitted after 31 December 2020 as new or updated NDCs in response to paragraphs 23-24 of decision 1/CP.21. This analysis shows that although all Parties provided information on mitigation targets, particularly for 2025 and 2030, the current GHG emission reduction from 2010 to 2030 is $0.5 \%$ instead of the $45 \%$ required by the Paris Agreement for a global warming limit of 1.5 degrees (UNFCCC, 2021).

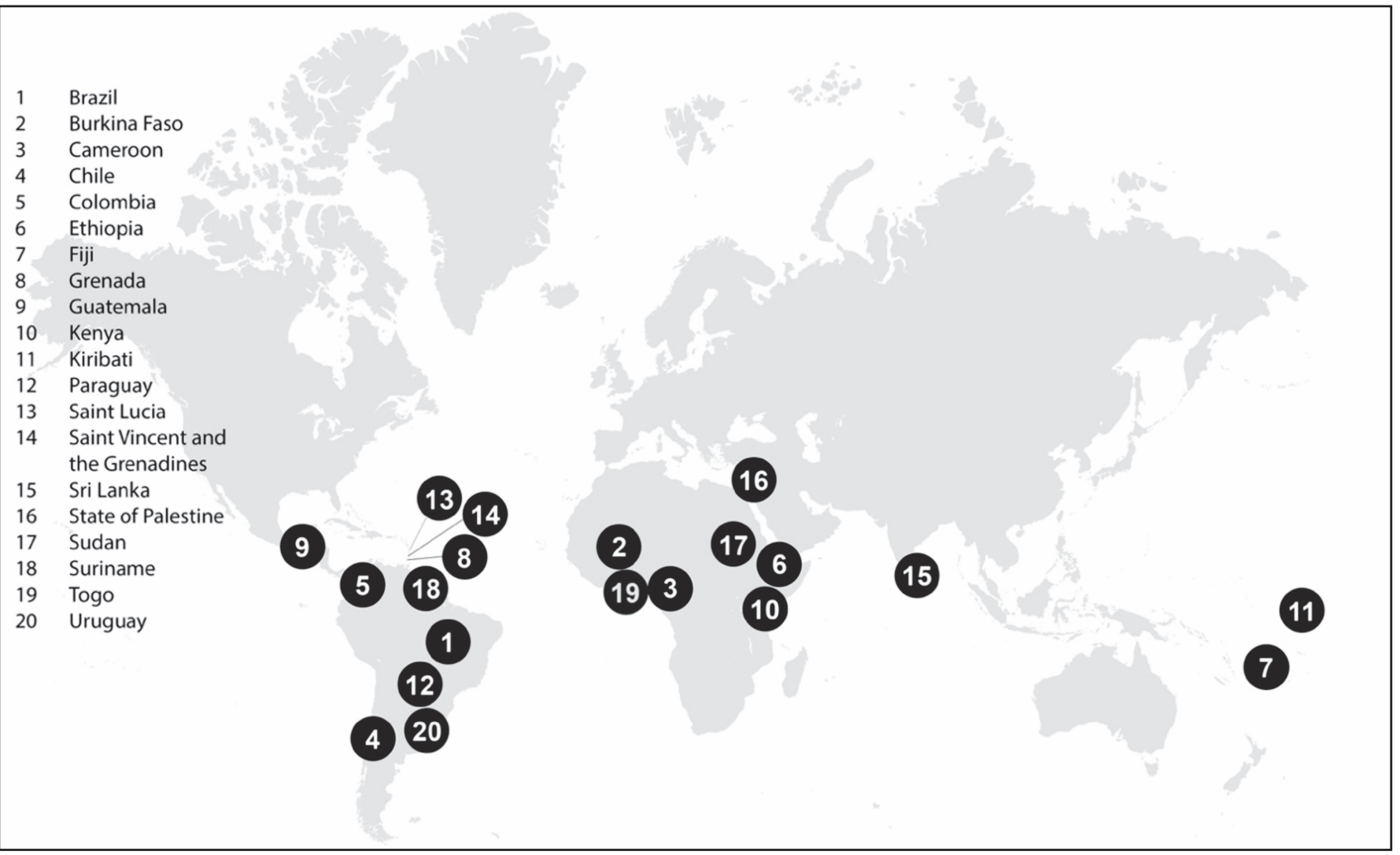

Figure 2 - Distribution of the 20 Countries that submitted NAPs between 2014 and 2020. 
After testing the methodology on one NAP, shortcomings identified and improvements made, the methodology will be applied to review and analysis on all National Adaptation Plans (NAPs) submitted before 31 July 2020, publicly available through the UNFCCC's online repository. A total of 20 NAPs representing 20 countries will be analyzed in-depth in their original languages, including French, Spanish, and English. The 20 countries are classified as least developed countries, or non-Annex I, by the United Nations General Assembly that officially submitted NAPs to the NAP Central of UNFCCC between 2014 to 2020 (Fig. 2). In particular: Brazil, Burkina Faso, Cameroon, Chile, Colombia, Ethiopia, Fiji, Grenada, Guatemala, Kenya, Kiribati, Paraguay, Saint Lucia, Saint Vincent and the Grenadines, Sri Lanka, State of Palestine, Sudan, Suriname, Togo, Uruguay.

The methodology is structured in four parts (Fig. 3).

In the first part, the NAPs will be read, looking for climate change and adaptation challenges and responses. The analysis aims to recognize adaptation challenges and the appropriate adaptation measures in the general structure of the NAPs and then focus on urban systems and human settlements (Fee et al., 2019).

In the second part, an excel dashboard composed of 172 indicators will be produced and filled with the data searched within the 20 NAPs, the NDCs and NUPs. This dashboard was designed to enable the future addition of the datasets for possible updating data. Following the NDCs' methodology, the indicators will be grouped into eleven groups based on four main strands: geographic and socio-economic data on the states analysed; general and introductory data on NAPs; information on urban content in national policies (NAPs, NDCs and NUPs); and links between national and international instruments and legislative references. The eleven groups are as follows:

- Geographic Indicators on: Country IOS code, Country name, Region name, Sub-Region name, Income categorization, Official language.

- General Indicators on population and GHG emissions.

- NAPs General Indicators on challenge and measure for climate change adaptation.

- NAPs Urban Indicators on urban challenge and urban measure for climate change adaptation.

- NDCs Indicators on urban adaptation and mitigation priorities.

- NUPs Indicator on: Presence of NUP; Name of NUP; Year of NUP; Form of NUP; Stage of NUP; National Urban Agency.

- Urban content in National Policies Indicators: including information on NAPs and NDCs.

- International policy linkages, with reference to SDGs, Sendai Framework for Disaster Risk Reduction (20152030); Paris Agreement; New Urban Agenda.

- National plans/policy/strategies/reports linkages on the adoption/presence of: National climate plan; National climate policy; National climate laws (legislative references); National climate actions; Mention of National climate policy/plan/law/actions in NAPs.

These groups of indicators have a different weight than the urban content analysis. Geographical indicators, general indicators, NDCs urban indicators, and NUP indicators are secondary indicators supporting the urban context analysis: they allow us to frame the climate and urban-related policies for each country. The main block consists of indicators on NAPs, urban content in national policies, and links between international and national policies.

In the third part, clusters of urban content will be assigned to each nation to compare urban content in the different NAPs, which will then be compared to the urban content of NDCs and NUPs, results of the urban content reviews developed by UN-Habitat and OECD (Organization for Economic Co-operation and Development) between 2017 and 2018. The main result of this work is the clustering of urban content, as follows:

- Cluster A: NAPs with urban dedicated sections and mentions within text headers, classified as strong urban content.

- Cluster B: NAPs with urban mention within the body of text, classified as moderate urban content.

- Cluster C: NAPs with no urban mention within the text and classified to have low or no urban content.

In the fourth part, the methodology addresses relationships among the urban content of the NAPs, the NDCs, and NUPs and the linkages between the climate-

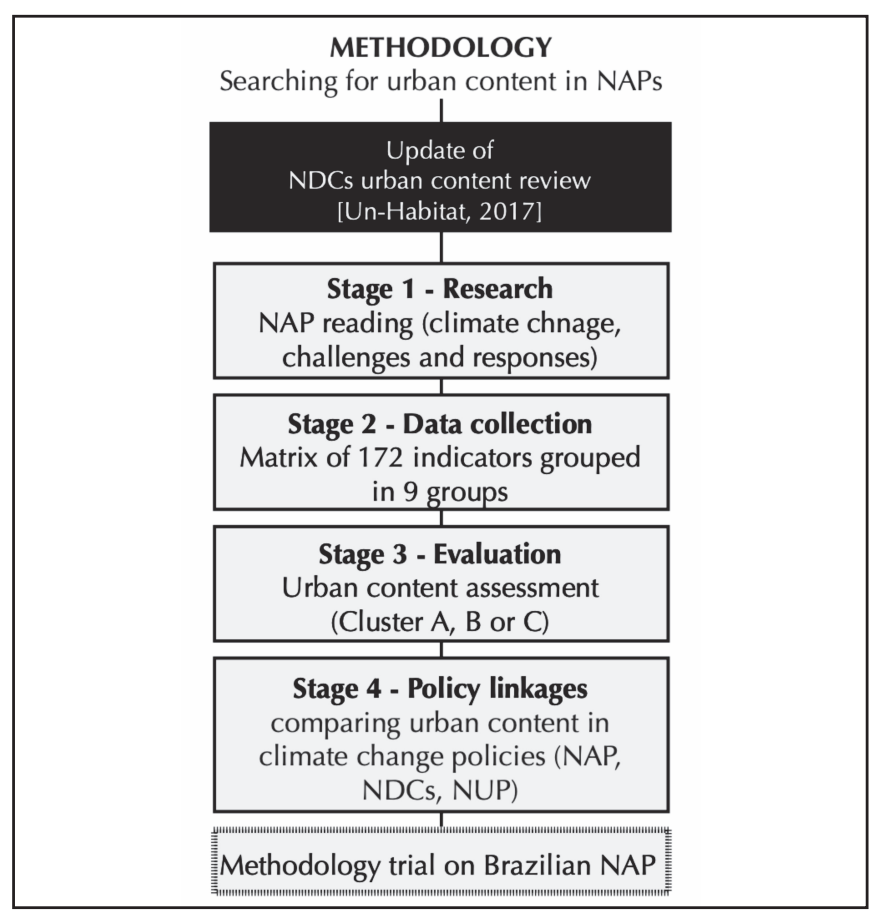

Figure 3 - Methodology flowchart: 4 stages for searching urban content in climate change adaptation policies. 
related plans, strategies, legislative on the international and national scale ${ }^{4}$.

Data will be principally replicated from United Nations and World Bank databases; the Sustainable Urbanization in the Paris Agreement, Comparative review for urban content in the Nationally Determined Contributions (NDCs) Report (Tollin, Hamhaber, et al. 2017); NAPs submitted to the UNFCCC and UN-Habitat databases; the OECD databases ${ }^{5}$.

\section{TESTING THE METHODOLOGY: THE URBAN CONTENT ASSESSMENT OF BRAZIL'S NAP}

To test the methodology's effectiveness, this paper will apply to one of the 20 countries that submitted the NAP before 2020. The chosen country is Brazil, as we expect to face numerous challenges imposed by climate change identified in the NAP due to its large surface area and large population. Therefore, the 172 indicators, grouped into 9 groups, were researched as follows.

\subsection{Geographic Indicators}

Brazil is the country with the largest surface area in the Americas region $(8,515,767$ square kilometres), and consequently has a very low population density of 25 inhabitants per square kilometres. Compared to the majority of the countries belonging to the non-Annex I, of which it is a member, which are characterized by low incomes, Brazil has a middle-high income.

\subsection{General Indicators}

Three main dynamics emerge from the analysis of demographic indicators: population growth, urbanization rate, and population living in slums. By 2019, with $211,049,527$ inhabitants, Brazil was the sixth most populous state in the world. In line with the world population growth trend, from 2011 to 2019, the population increased by $+6.85 \%$. Concerning rapid urbanization, in 2019, the urban population represented

\footnotetext{
${ }^{4}$ The international link means a connection between Sendai Framework for Disaster Risk Reduction, Paris Agreement, and New Urban Agenda, and national link means climate and urban considerations in policy, strategy, action, plan or legislative reference in the national context.

${ }^{5}$ The data used in this research is drowning from UN-Habitat and OECD reports. More in detail Geographical and General indexes include indicators and data collected from United Nations and World Bank databases; NDCs index is from the Sustainable Urbanization in the Paris Agreement, Comparative review for urban content in the (NDCs) Report (Tollin et al., 2017); NAPs indexes are from countries' NAPs submitted by United Nation Framework Convention on Climate Change (UNFCCC) and UN-Habitat databases; NUPs index is from the Organization for Economic Cooperation and Development (OECD) databases.
}

$86.8 \%$ and is expected to reach $90.9 \%$ of the national population in 2050 . Moreover, in $2018,16 \%$ of the population lived in slums. Turning to the analysis of socio-economic data, Brazil's GDP per capita is USD 15,259, and the Human Development Index (HDI) is high, at 0.761 (Tab. 1).

Tabble 1 - Brazil overview of socio-economic data

\begin{tabular}{l|l} 
Region & Americas \\
\% urban pop. (2019) & $86.8 \%$ \\
\hline$\%$ urban pop. (2050) & $90.9 \%$ \\
\hline Pop. Density (2019) & 25 inhabitants $/ \mathrm{km}^{2}$ \\
\hline Income (2020) & Upper-middle \\
\hline HDI (2018) & High \\
\hline GDP per capita \$ (2019) & 15.259
\end{tabular}

\subsection{NAPs General Indicators}

The NAP, titled "National Adaptation Plan to Climate Change", was proposed by the Federative Republic of Brazil in collaboration with the Minister of Environment. It was submitted in 2015, the same year of the NDCs, in English. The plan is structured in two volumes: Volume I, titled General strategy, contains the introduction, the methodology and the goal of the plan; Volume II, titled Sectoral and thematic strategies, includes in-depth strategies concerning 11 sectors (agriculture; biodiversity and ecosystems; cities; disaster risk management; industry and mining; infrastructure; vulnerable population; water resources; health; food and nutritional security; coastal zone). For each sector, it is defined general objective, introduction, institutional and legal framework, qualitative vulnerability analysis, guidelines (goal, initiatives and responsible), adaptation measures for the sector, and interdependence with other sectors.

From this perspective of climate change adaptation, the plan has policy and strategic content and at the national scale. Actions at the local scale are absent. Moreover, the NAP does not mention loss and damage and the cost of inaction; otherwise, it presents a monitoring and evaluation plan.

In the analysis were identified two elements (Table 2): the main climate challenges that make adaptation urgent in the nation, and measures identified to address climate change.

Floods, drought, storm events (rainfall, cyclones etc.), temperature rise, heatwaves, land degradation, saltwater intrusion and coastal erosion are the climate effects mentioned by the NAP. Brazil is affected by eight of the ten impacts analysed in the methodology, which means that the country has a high vulnerability to climate change. Moreover, the plan identifies challenges and 
A Methodological Framework to Assess the Urban Content in Climate Change Policies

Table 2 - Brazilian NAP: General Indicators

\begin{tabular}{l|l} 
CHALLENGES & $\begin{array}{l}\text { Climate } \\
\text { Change }\end{array}$ \\
\hline Macro sectors & $\begin{array}{l}\text { [all] Adaptation, mitigation, institutional } \\
\text { intrusion, coastal erosion } \\
\text { capacity, technical capacity, finance }\end{array}$ \\
\hline Sectors & $\begin{array}{l}\text { Food security, biodiversity, water } \\
\text { management, health, specific industries, } \\
\text { improved governance and infrastructure }\end{array}$ \\
\hline MEASURES & $\begin{array}{l}\text { Adaptation, institutional capacity, technical } \\
\text { capacity, finance }\end{array}$ \\
\hline Sectors sectors & $\begin{array}{l}\text { Transport, water, energy, food production, } \\
\text { land use and planning, industry, health }\end{array}$
\end{tabular}

responses for adaptation, mitigation, institutional capacity, technical capacity and finance (Table 3). The analysis of these issues shows that the country has difficulties mobilizing funding to make the adaptation strategies effective. Moreover, the plan underlines the unpreparedness of institutions in dealing with climate change. At the same time, for each strategy is defined a budget and the institution responsible for its implementation. Thus, it can be seen that a problem is readily identified as a solution.

Table 3 - Brazilian NAP: Analysis of challenges and measures related to macro sectors

\begin{tabular}{c|c|c}
\hline MACRO SECTORS & CHALLENGES & MEASURES \\
Mitigation & Yes & No \\
\hline Institutional capacity & Yes & Yes \\
\hline Technical capacity & Yes & Yes \\
\hline Finance & Yes & Yes
\end{tabular}

Concerning the sectors, once identified as vulnerable to climate change are food security, biodiversity, water management, health, specific industries, improved governance and infrastructure. Consequently, the sectors in which adaptation responses have been prepared are transport, water, energy, food production, land use and planning, industry and health.

\subsection{NAPs Urban Indicators}

The same indicators used to analyse the adaptation content of the NAPs were used to investigate the urban content within NAPs. Starting from the macro sectors, the Brazilian's NAP present both challenges and measures only concerning institutional capacity (Tab. 4).

More in detail, the vulnerability of urban systems is stated from the plan's introduction: it is that one of the 11
Table 4 - Brazilian NAP: Analysis of adaptation urban content in relation to macro sectors

\begin{tabular}{c|c|c|}
\hline MACRO SECTORS & CHALLENGES & MEASURES \\
Mitigation & Yes & No \\
\hline Institutional capacity & Yes & Yes \\
\hline Technical capacity & No & No \\
\hline Finance & No & Yes
\end{tabular}

strategies identified is "cities". The analysis showed that urban systems are mainly affected by floods, storm events, and temperature rise (also think to the heat island), especially in land use management, vulnerability and disaster, water management, improved governance, and infrastructure. Solutions are mainly found in the fields of land use and planning, health, and society. The urban content is more present in the strategic content, not very effective in the implementation at the urban scale.

Table 5 - Brazilian NAP: Urban Indicators summary

\begin{tabular}{l|l} 
CHALLENGS & $\begin{array}{l}\text { Floods, storm events, temperature } \\
\text { rise }\end{array}$ \\
\hline Macro sectors & $\begin{array}{l}\text { Adaptation, mitigation, institutional } \\
\text { capacity }\end{array}$ \\
\hline Sectors & $\begin{array}{l}\text { Land use management and urban } \\
\text { planning, water management, } \\
\text { improved governance and } \\
\text { infrastructure }\end{array}$ \\
\hline MEASURES & $\begin{array}{l}\text { Adaptation, institutional capacity, } \\
\text { finance }\end{array}$ \\
\hline Sectors & $\begin{array}{l}\text { Land use and planning, health, } \\
\text { society }\end{array}$
\end{tabular}

\subsection{NDCs Indicators}

In 2015, the Federative Republic of Brazil communicated to the Secretariat of the United Nations Framework Convention on Climate Change (UNFCCC) that Nationally Determined Contribution (NDC) to reduce greenhouse gas emissions by $37 \%$ below 2005 levels in 2025. The NDC's urban content review highlights that Brazil's NDCs identified urban adaptation but not mitigation priorities (Tollin, Hamhaber, et al. 2017). In the review, mitigation priorities refer to priorities that are not necessarily explicitly urban but relevant for urban environments, focusing on: energy, transport, building, waste, water, industrial efficiency, reduction of non-CO2 GHG, improved governance. Instead, adaptation priorities refer generic priorities not necessarily urban related, and include food security, land use management, 
vulnerability and disasters, biodiversity and/ or ecosystems conservation, water management, health/ health care, specific industry, improved governance, further adaptation priorities.

\subsection{NUPs Indicator}

The role of National Urban Policy (NUP) was established during the United National Conference on Housing and Sustainable Urban Development (Habitat III) occurred in Quito, Ecuador, in October 2016. The outcome document was the New Urban Agenda (NUA), an action-oriented document to drive sustainable urban development at the local level (NUA, 2016), which identifies NUP "as one of the key tenants for achieving sustainable development and growth" (OECD, 2018, p. vi). As reported in the OECD Report (2018), the Brazilian NUP, titled "Statute of the City", was presented in 2002 by the National Development Council; no information was provided on the form and stage of the NUP.

\subsection{Urban content in National Policies}

The data collected on climate change, adaptation challenges and responses identified so far allowed to assign the urban content cluster to the Brazil NAP. The result is that in Brazil the NAP has urban cluster A (strong) and identified urban adaptation and mitigation priorities, while identifying adaptation-only responses, including "implementation of public policies for urban development that combine urban planning and risk management within a prevention perspective" (Federative Republic of Brazil, 2016, p.58). This result was compared with the urban content identified in the Brazil's NDCs by UN-Habitat (2017), which shows that NDCs has cluster B (moderate), and that it identified only urban adaptation priorities. The urban content of the NUP has not been classified because it is a purely urban policy.

\subsection{International policy linkages}

In the NAP, Brazil considers and mentions the Paris Agreement (2015) and the Sendai Framework for disaster risk reduction agreed between the UN member countries at the Third World Conference on Disaster Risk Reduction. The plan does not mention the SDGs.

\subsection{National plans/policy/strategies/reports linkages}

Finally, it was searched what Brazilian climate-related policies, plans, and strategies only mentioned in the NAP (e.g., national climate plan or strategy). The NAP analysis shows that Brazil has adopted: National Plan for Climate Change; National Policy for Climate Change (PNMC- Law 12.187/09) and its enabling decree (Decree 7.390/10);
Brazilian Panel on Climate Change (PBMC); and National Civil Defence and Protection Policy, instituted by Law 12.608, of 10 of April 2012.

\section{CONCLUSION. MOVING A STEP FORWARD IN ASSESSING URBAN CONTENT IN CLIMATE CHANGE POLICIES}

From the test conducted on Brazil's NAP, it is possible to state that the NAPA methodology is functional in defining the NAP's urban cluster and the challenges and responses, both NAPA for adaptation and the urban content. The strength of the NAPA methodology lies in its updatability: the methodology can be developed and updated based on emerging and future NAP priorities and on other issues arising from the scientific and grey literature. The methodology can be repeated, modified, and used for different purposes: for example, it can be used to analyse other climate-related policies concerning urban content or to research various topics within NAPs, such as water or energy use. However, the methodology's analysis highlighted some weaknesses and possible improvements, which will be illustrated below.

Starting from the Geographic Indicators, a more in-depth geographic analysis would help understand the contest in which each nation is embedded, allowing for a better analysis of climate change's vulnerabilities and impacts. It would be necessary to introduce indicators on each state's morphology, hydrography, soils, flora, and fauna. To give some examples, knowing the morphology of a country would lead to the identification of the most vulnerable areas in the territory. Moreover, the study of climate would allow the prediction of peak temperature rises, and the study of the composition of soils would allow the study of soil erosion. Lastly, a hydrography study would identify the vulnerabilities concerning large watercourses or to the sea. These analyses should be traced back to the main effects of climate change identified in the NAPs.

Moving to the General Indicators, to make the indicators easier to read and analyse, it would be necessary to compare national data with continental data. The income categorization, percentage of the population and urban population increase, percentage of the population living in slums, population density, Gross Domestic Product (GDP) per capita, and Human Development Index (HDI) should be reported on a continental scale to have a reference quantity as well as a term of comparison. This consideration is even more necessary given the twenty states' geographic dispersion that submitted NAPs between 2014 and 2020, which varies from Fiji to Kenya, from Sri Lanka to Colombia. Besides, it would be useful to add indicators on the age of the population, which would allow for considerations of vulnerable segments of the population and educational attainment (literacy).

Looking at NAPs General Indicators, the title, date, language, proposer, content, scale, and timeline are 


\section{A Methodological Framework to Assess the Urban Content in Climate Change Policies}

considered sufficient information to introduce the NAP. Other indicators can be combined, for example, by adding the sectors explored in the policy, such as water, agriculture, forestry, waste, health, etc., mainly if the methodology is used, as in this case, to search for specific content (e.g., urban containment). Regarding the assessment of adaptation challenges and responses, once researched for the twenty states that adopted NAPs between 2014 and 2020, the results should be used to define new NAP process guidelines.

Concerning NAPs Urban Indicators, the results of urbanscale adaptation challenges and responses can be used in the development of new UN-Habitat guidelines to strengthen urban content in NAPs. A "mention of specific cities" indicator can be added in the methodology to identify easier the cities with the most weaknesses or opportunities for climate change adaptation in each country.

Analysing the NDCs Indicators, the 2017 NDCs urban content review highlights the submission of NDCs, the urban content cluster, and the presence of adaptation and/or mitigation priorities. The analysis results should make explicit whether the NDCs have identified adaptation and mitigation responses and actions. The NDC results are mainly reported on the continental scale: it would be interesting to build more national fact sheets that would allow more convenient reading and understanding of the results.

Concerning NUPs Indicators, the OECD and UN-Habitat review (2018) was an analysis of the status of NUP progress. Since NUPs, by definition, the methodology could be used to research climate content in NUPs. The indicators should be translated from climate adaptation. Still, clusters could always be used to define the level of climate content: strong (cluster A), moderate (cluster B), low or no climate content (cluster C).

Comparing urban content in different policies at the national level, such as NAPs and NDCs, is useful: for UNHabitat to understand how to improve guidelines to strengthen urban content in climate policies; for countries to understand whether they have integrated urban content effectively in comparison with other states and to share experience and best practices. The comparison would be extended to other policies, strategies, and climate plans to have a complete climate picture for each nation.

Concerning international policy linkages, it was stated that methodology reports only the international policies and agreements mentioned in the NAPs. Regarding the analysis of urban content, it would be appropriate to study the policies adopted in each nation to define whether and how urban content has been considered.

The last group of indicators, which includes national plans/policy/strategies/reports linkages, contains only the climate-related policies, strategies, plans, and legislative references mentioned within the NAP. This analysis has, so far, some critical issues because, for example, each country names its climate policies differently, making it difficult even to find them. Moreover, they are very differentiated in content and structure. It would be necessary to propose international guidelines for their formation to be easier to compare results and exchange good practices between countries. Therefore, it would be necessary to identify all climaterelated policies, strategies and legislative references developed at the national scale by investigating their urban content: this would allow to have an integrated picture of climate policies at the national scale.

In a nutshell, to make the NAP's urban content review a functional tool for national and local governments to implement climate actions, the methodology should be replicated across all countries that submitted NAPs up to the present. Reviewing the urban content would help UnHabitat define a stronger focus on implementing climate action within new guidelines that strengthen the urban content in NAPs. Secondly, it will allow nations to understand their policies' limitations or strengths while also comparing their results with those of other countries.

\footnotetext{
* Maria Pizzorni, University of Southern Denmark. Civil and Architectural Engineering Department, Odense, Danimarca e-mail: mpiz@iti.sdu.dk

** Ombretta Caldarice, Politecnico di Torino. Responsible Risk Resilience Centre. Interuniversity Department of Regional and Urban Studies and Planning, Turin, Italy

e-mail: ombretta.caldarice@polito.it

*** Nicola Tollin, University of Southern Denmark. Civil and Architectural Engineering Department, Odense, Denmark e-mail:nto@iti.sdu.dk
}

\section{Contributo degli autori}

This paper is the result of the combined research activity of the authors. Nonetheless, Maria Pizzorni authors the final version of section 3; Ombretta Caldarice authors the final version of the section 1, Nicola Tollin authors the final version of the sections 2 and 4 . 


\section{Bibliography}

AYLETT A., Institutionalizing the urban governance of climate change adaptation: Results of an international survey, Urban Climate, Vol. 14, 2015, pp. 4-16.

DOI:https://doi.org/10.1016/j.uclim.2015.06.005

Berrang-Ford L., Ford J.D., Paterson J., Are we adapting to climate change?, Global Environmental Change, Vol. 21(1), 2011, pp. 25-33.

DOI:https://doi.org/10.1016/j.gloenvcha.2010.09.012.

BerRANG-Ford L., Ford J.D., LeSNIKOWSKI A. et al., What drives national adaptation? A global assessment, Climatic Change, 2014. DOI: 10.1007/s10584-014-1078-3.

Brunetta G., Caldarice O., Toluin N. et al., Urban Resilience for Risk and Adaptation Governance. Theory and Practice, Springer International Publishing, 2019.

DOI: 10.1007/978-3-319-76944-8.

Carmin J.A., Anguelovski I., Roberts D., Urban climate adaptation in the global south: Planning in an emerging policy domain, Journal of Planning Education and Research, 2012. DOI: $10.1177 / 0739456 \times 11430951$.

Datta A., Shaban A., Mega-Urbanization in the Global South: Fast Cities and New Urban Utopias of the Postcolonial State, 2016. DOI: $10.4324 / 9781315797830$.

Evans J.P., Resilience, ecology and adaptation in the experimental city, Transactions of the Institute of British Geographers, 2011.

DOI: 10.1111/j.1475-5661.2010.00420.x.

Federative Republic Of Brazil, National Adaptation Plan to Climate Change, 2017.

FeE L., MAYr M., WANG Y. et al., Addressing Urban and Human Settlement Issues in National Adaptation Plans: A Supplement to the UNFCCC Technical Guidelines on the National Adaptation Plan Process, Nairobi, 2019 (downloadable from the website: https://www4. unfccc.int/sites/NAPC/Documents/Supplements/NAP-Hu man Settlement.pdf).

Hallegatte S. And Corfee-Morlot J., Understanding climate change impacts, vulnerability and adaptation at city scale: An introduction, Climatic Change, 2011.

DOI: 10.1007/s10584-010-9981-8.

HARMAN B.P., TAYLOR B.M., LANE M.B., Urban partnerships and climate adaptation: challenges and opportunities, Current Opinion in Environmental Sustainability, Vol. 12, pp. 74-79.

DOI: https://doi.org/10.1016/j.cosust.2014.11.001.

Masson V., Marchadier C., Adolphe L. et al., Adapting cities to climate change: A systemic modelling approach, Urban Climate, 2014.

DOI: 10.1016/j.uclim.2014.03.004.

MatTHEWs T., Climate Change Adaptation in Urban Systems: Strategies for Planning Regimes, Program, 2011.

MeErow S., Newell J.P., Urban resilience for whom, what, when, where, and why?, Urban Geography, Vol 40(3), 2019.

DOI: 10.1080/02723638.2016.1206395.

Meerow S., Newell J.P., Stults M., Defining urban resilience: $A$ review. Landscape and Urban Planning, Vol. 147, 2016, pp. 3849. DOI:https://doi.org/10.1016/j.landurbplan.2015.11.011.

OECD, Global State of National Urban Policy. Global State of National Urban Policy, 2018.

DOI: 10.1787/9789264290747-en.

Olazabal M., Ruiz De Gopegui M., Adaptation planning in large cities is unlikely to be effective, Landscape and Urban Planning, 2021.

DOI: 10.1016/j.landurbplan.2020.103974.

Plescia-Boyd A., Un-Habitat et al., Enhancing Nationally Determined Contributions through Urban Climate Action, Nairobi, 2020. Available at: https://unhabitat. org/sites/default/files/2020/06/ndc_guide_19062020.pdf.

Prieur-Richard A.-H., Walsh B., Craig M. et al. Global Research and Action Agenda on Cities and Climate Change Science, 2018 (downloadable from the website:https://www. ipcc.ch/site/assets/uploads/2019/07/Research-Agenda-Aug10_Final_Short-version.pdf).

ROMERO LANKAO P., QIN H., Conceptualizing urban vulnerability to global climate and environmental change. Current Opinion in Environmental Sustainability, Vol. 3(3), 2011, pp. 142-149. DOI: 10.1016/j.cosust.2010.12.016.

SIMON D., New evidence and thinking on urban environmental change challenges, International Development Planning Review, 2014.

DOI: 10.3828/idpr.2014.9.

Tollin N., Hamhaber J., Grafakos S. et al. Sustainable Urbanization in the Paris Agreement. Comparative review for urban content in the Nationally Determined Contributions (NDCs), United Nations Human Settlements Programme (UN-Habitat), 2017 (downloadable from the website:https:/unhabitat. org/sites/default/files/downloadmanager-files/Paris Agre ement_25_Jan-2019_for EmailOnline.pdf).

UNFCCC, United Nations Framework Convention, 1992 (downloadable from the website: https://unfccc.int/ resource/docs/convkp/conveng.pdf).

UNFCCC, National adaptation plans: Technical guidelines for the national adaptation plan process, Least Developed Countries Expert Group, 2012.

UNFCCC, Nationally determined contributions under the Paris Agreement. Synthesis report by the secretariat, 2021 (downloadable from the website:http://unfccc. int/resource/docs/2009/cop15/eng/11a01.pdf).

UNITED NATIONS, Paris Agreement - UNFCCC. Conference of the Parties on its twenty-first session, 2015.

DOI: $10.1017 /$ S0020782900004253.

VinCENT K., CUNDILl G., The evolution of empirical adaptation research in the global South from 2010 to 2020, Climate and Development, 2021.

DOI: 10.1080/17565529.2021.1877104.

Williams B., Statement of Climate Change. Un Habitat. Nairobi, Kenya, 2007 (downloadable from the website: https://sustainabledevelopment.un.org/content/docume nts/habitat_2may_cc.pdf). 


\section{Valutare il contenuto}

urbano nelle politiche di adattamento al cambiamento climatico:

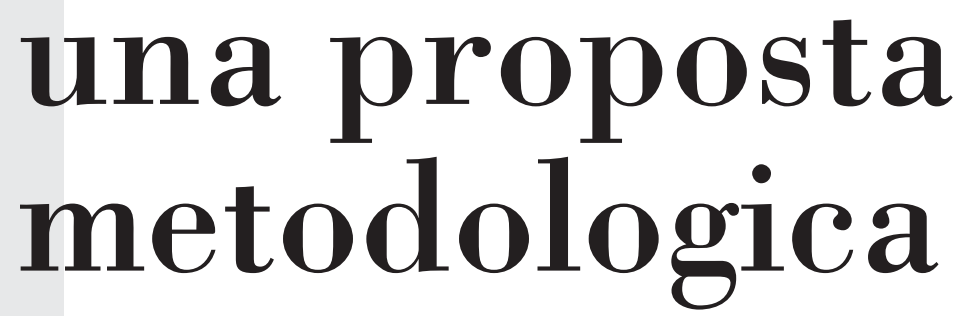

Maria Pizzorni*, Ombretta Caldarice**, Nicola Tollin*** parola chiave: sud del mondo, adattamento, cambiamento climatico, Nationally Determined Contributions (NDCs), pianificazione strategica e territoriale,

\section{Abstract}

Entro il 2050, la popolazione urbana rappresenterà il 68\% della popolazione mondiale. Di questa, I'80\% sarà concentrata in Asia e in Africa. A partire da questo scenario di incrementale urbanizzazione, nel 2011 la Convenzione quadro delle Nazioni Unite sui cambiamenti climatici (UNFCCC) ha introdotto, nell'ambito del Cancún Adaptation Framework (CAF), i Piani Nazionali di Adattamento (NAP). I NAP sono concepiti come strumento a supporto dei Paesi inclusi nel Non-Annex I, descritti dall'Assemblea generale dell'ONU come particolarmente vulnerabili alle transizioni in atto, per identificare le sfide e progettare le risposte più appropriate verso l'adattamento in risposta al cambiamento climatico. Riconoscendo la crescente vulnerabilità dei sistemi urbani, UN-Habitat nel 2019 ha predisposto delle linee guida per supportare la redazione dei $N A P$, in particolare per includere le questioni urbane e gli insediamenti umani. A dieci anni dall'entrata in vigore del $C A F$, il presente articolo presenta una proposta metodologica per valutare il contenuto urbano dei NAP. L'approccio valutativo proposto è un aggiornamento dalla metodologia utilizzata per analizzare il contenuto urbano dei Nationally Determined Contributions (NDCs), pubblicata da UN-Habitat nel 2017, e qui adattata ai NAP. La metodologia mira ad analizzare sia le sfide chiave per l'adattamento, ma anche le risposte esplicitamente o implicitamente connesse ai sistemi urbani e l'interconnessione del contenuto urbano dei NAP in relazione ad altre politiche chiave, quali NDCs e NUP (Politiche Urbane Nazionali). In questa prospettiva, la metodologia si compone di 172 indicatori, raggruppati in nove gruppi: (i) Indicatori geografici; (ii) Indicatori generali; (iii) Indicatori generali dei NAP; (iv) Indicatori che leggono il contenuto urbano dei NAP; (v) Indicatori degli NDC; (vi) Indicatori dei NUP; (vii) Indicatori che analizzano il contenuto urbano delle politiche nazionali; (viii) Collegamenti con le politiche internazionali (inclusi SDGs, Sendai Framework for Disaster Risk Reduction, Accordo di Parigi e New Urban Agenda); e (ix) Collegamenti nazionali tra piani/politiche/strategie/ report. La metodologia è stata testata sul NAP del Brasile, al fine di individuare considerazioni generali da adottare anche per gli altri Paesi del sud del mondo che hanno presentato i loro NAP tra il 2014 e il 2020. In sintesi, questa sperimentazione ha mostrato che: (i) vi è una maggiore attenzione alla definizione delle sfide di adattamento al clima più che all'individuazione di risposte; (ii) le sfide e le risposte di adattamento al cambiamento climatico sono prevalentemente identificate su scala nazionale; (iii) il NAP del Brasile si caratterizza per un alto contenuto urbano. In conclusione, il paper mette in luce punti di forza e criticità della metodologia, identificando alcuni miglioramenti per ciascuno dei nove gruppi di indicatori, nella prospettiva di applicare questo approccio di valutazione anche in altri contesti territoriali. 


\section{INTRODUZIONE. PER UNA INTEGRAZIONE DELL'ADATTAMENTO AL CAMBIAMENTO CLIMATICO ALLA SCALA LOCALE}

Viviamo oggi in un pianeta sempre più urbanizzato; il 55\% della popolazione mondiale vive nelle città, luoghi che consumano il $75 \%$ dell'energia globale, emettono l' $80 \%$ delle emissioni di gas serra, producono l' $80 \%$ del prodotto interno lordo globale (Fee et al., 2019; Williams, 2007). Come sottolineato da UN-Habitat, la rapida urbanizzazione, la migrazione incontrollata e l'esaurimento delle risorse colpiranno con più forza i Paesi inclusi nella lista Non-Annex I stilata da UNFCCC, che comprende i Paesi in via di sviluppo identificati come maggiormente vulnerabili (UNFCCC, 1992). La loro debolezza è ancora più evidente se guardiamo le proiezioni future: entro il 2050, I' $80 \%$ della popolazione urbana mondiale si concentrerà proprio in Asia e Africa (Plescia-Boyd et al., 2020). Queste aree - già particolarmente fragili a causa della estrema povertà, della alta presenza di insediamenti informali e dalla mancanza di infrastrutture - saranno meno pronte per affrontare gli effetti del cambiamento climatico (Carmin et al., 2012; Datta and Shaban, 2016; Evans, 2011). In particolare, I'assenza di alcuni servizi essenziali comprometterà la loro capacità di rispondere rapidamente ed efficacemente alle sfide imposte dai cambiamenti in corso (Romero Lankao e Qin, 2011).

Oltre alla rapida crescita della popolazione, i sistemi urbani sono esposti ad altri fattori che accrescono la loro complessità, quali ad esempio disastri naturali, crisi economiche, instabilità politica (Fee et al., 2019; Hallegatte and Corfee-Morlot, 2011; Meerow et al., 2016). In particolare, gli effetti del cambiamento climatico hanno un impatto negativo sulle città e assumono il ruolo di moltiplicatori delle altre criticità urbane, rendendo i sistemi territoriali sempre più vulnerabili. Le aree urbane contribuiscono perciò al cambiamento climatico e allo stesso tempo soffrono i suoi effetti, diventandone quindi sia vittime che colpevoli (Carmin et al., 2012; Matthews, 2011). In questo senso, quindi, integrare le questioni urbane nelle azioni climatiche locali diventa imperativo per affrontare le sfide urbane in relazione al cambiamento climatico, diminuendo le vulnerabilità e migliorando la capacità di adattamento dei sistemi urbani (Fee et al., 2019).

In questa prospettiva, il legame tra rapida urbanizzazione, sviluppo economico e effetti del cambiamento climatico può essere trovato nell'adattamento in una prospettiva di resilienza trasformativa (Brunetta e Caldarice, 2020). Come descritto dall'IPCC (2018, p. 55), I'adattamento trasformativo " changes the fundamental attributes of a socio-ecological system in anticipation of climate change and its impacts". Inoltre, il Coalition for Urban Transitions Report (2019) sottolinea che le città possono e devono essere catalizzatori significativi nell'implementazione di azioni di adattamento e mitigazione del clima, in particolar modo nell'affrontare molteplici crisi concomitanti. Pertanto, l'adattamento è necessario per rendere gli insediamenti attuali e futuri resilienti e pronti a gestire gli effetti della transizione in atto.

Come sottolineato da Olazabal e Ruiz De Gopegui (2021), l'adattamento nelle grandi città non è oggi ancora efficace. Gli autori hanno analizzato le azioni di contrasto al cambiamento climatico di 59 città costiere. Nel campione selezionato sono stati valutati progressi, efficacia e sostenibilità delle politiche pubbliche di adattamento. L'analisi ha dimostrato che la pianificazione per l'adattamento nelle grandi città costiere è inefficace a causa dell'insufficiente riduzione delle vulnerabilità territoriali, del mancato aumento della resilienza e della prevalenza di azioni a breve termine. Gli autori ritengono che per superare questi limiti, l'adattamento alla scala urbana debba essere integrato con i quadri istituzionali al fine di garantire la presenza e l'efficacia delle azioni di adattamento a lungo termine.

In una prospettiva più generale, numerosi altri autori hanno identificato le barriere all'adattamento (BerrangFord et al., 2014; Harman et al., 2015; Masson et al., 2014; Meerow and Newell, 2019; Simon, 2014). Tra le tante, la mancanza di capacità istituzionale e di costruzione di una governance climatica aumenta la difficoltà di sviluppare e attuare strategie di adattamento ai cambiamenti climatici, compromettendo il progresso dell'adattamento a scala globale (Berrang-Ford et al., 2011, 2014). In più, la mancanza di dati e indicatori per quantificare l'adattamento rende difficile valutare la sua efficacia, dando vita a sistemi di valutazione e monitoraggio che quindi non sono in grado di supportare il processo decisionale (Berrang-Ford et al., 2011; Olazabal and Ruiz De Gopegui, 2021). Inoltre, i Governi nazionali stanno affrontando chiare sfide nel rafforzamento della capacità istituzionale e nell'accesso alle risorse finanziarie e nuove tecnologie. Infine, la mancanza di un approccio multi-scalare all'adattamento limita l'effettiva armonizzazione e l'allineamento delle politiche nazionali con le azioni locali, e in particolare a livello urbano (Aylett, 2015; Meerow e Newell, 2019; Romero Lankao e Qin, 2011). Affinché l'adattamento ai cambiamenti climatici sia proattivo nella gestione della transizione in atto, è necessario rafforzare il processo decisionale in modo che questo sia basato su dati concreti e sull'integrazione verticale dei contenuti urbani tra politiche nazionali e azioni locali (Fee et al., 2019). Inoltre, si ritiene che le sfide imposte dai cambiamenti climatici debbano diventare priorità sistematiche nel processo di pianificazione alla scala locale, al fine di trasformare le sfide in azioni in una prospettiva di adattamento mainstreaming (Brunetta et al., 2019).

II processo di adattamento è sempre più accompagnato da politiche internazionali tratteggiate prevalentemente nell'ambito della Convenzione quadro delle Nazioni Unite sui Cambiamenti Climatici (UNFCCC). In particolare, i piani nazionali di adattamento (NAP) sono stato istituiti da UNFCCC nell'ambito del Cancún Adaptation Framework (CAF) nel 2011. L'obiettivo principale dei NAP è costruire la capacità di adattamento per ridurre gli effetti 
dei cambiamenti climatici integrando l'adattamento nelle politiche settoriali. Riconoscendo la crescente vulnerabilità dei sistemi urbani, UN-Habitat nel 2019 ha predisposto delle linee guida per supportare la redazione dei NAP, in particolare per includere le questioni urbane e gli insediamenti umani (Fee et al., 2019): con questo documento UN-Habitat raccomanda alle nazioni l'identificazione delle sfide imposte dai cambiamenti climatici e la definizione di misure di adattamento alla scala urbana. Sulla scorta di questo documento, UN-Habitat ha pubblicato nel 2017 una prima revisione del contenuto urbano condotta sui Nationally Determined Contributions (NDCs): dai risultati dell'analisi è emerso che i Paesi, seppur individuando in maniera esaustiva le sfide imposte dal cambiamento climatico, difficilmente identificano le risposte di adattamento alla scala urbana. Inoltre, I'analisi mostra che i Paesi in via di sviluppo hanno un maggiore contenuto urbano rispetto a quelli sviluppati. Questi risultati giustificano la necessità di un'analisi integrata del contenuto urbano di NDCs e NAP, che permetterebbe di evidenziare la presenza o l'assenza di sfide e risposte esplicite sull'adattamento al clima a livello locale. In parallelo, I'OCSE nel 2018 ha pubblicato, in collaborazione con UNHabitat, il Global State of National Urban Policy Report (OECD, 2018), ossia una revisione dello stato di attuazione delle NUP (National Urban Policies) in 150 Paesi (su 193 Stati membri delle Nazioni Unite).

Alla luce delle molteplici pressioni subite dai sistemi urbani (climatiche e non), del ruolo fondamentale dell'azione locale nell'affrontare i cambiamenti climatici e della direzione presa dalle politiche internazionali, questo articolo si concentra sulla relazione tra la dimensione urbana e le politiche di adattamento al cambiamento climatico. L'articolo presenta la metodologia progettata per sviluppare una valutazione preliminare del contenuto urbano dei Piani nazionali di adattamento (NAP). Dopo la presente l'introduzione, il paragrafo 2 descrive la metodologia a partire dall'analisi dei 172 indicatori che la compongono. Nel paragrafo 3, viene analizzato il NAP del Brasile di cui saranno presentati i principali caratteri. Il paragrafo 4 è dedicato ad alcune considerazioni conclusive in cui vengono messe in luce punti di forza e criticità della metodologia, identificando alcuni miglioramenti per ciascuno dei nove gruppi di indicatori, nella prospettiva di applicare questo approccio di valutazione anche in altri contesti territoriali.

\section{SVILUPPO DELLA METODOLOGIA PER VALUTARE IL CONTENUTO URBANO NELLE POLITICHE DI ADATTAMENTO AL CAMBIAMENTO CLIMATICO}

La valutazione del contenuto urbano nelle politiche di adattamento al cambiamento climatico è finalizzata a rafforzare l'inclusione esplicita delle sfide e delle risposte urbane all'interno dei processi di programmazione nazionali. Questo dovrebbe essere motivazione per orientare una più consapevole elaborazione di politiche evidence- based che integrino azioni di adattamento ai cambiamenti climatici in una prospettiva di governance multilivello. Pertanto, evidenziare le attuali carenze nell'implementazione del contenuto urbano nelle politiche di adattamento ai cambiamenti climatici è punto di partenza per la definizione di nuove linee guida che rafforzino il contenuto urbano nelle politiche (inter)nazionali e capaci di colmare il divario nel passaggio dalle politiche nazionali alle azioni locali.

Come descritto in Figura 1, il contenuto urbano verrà ricercato all'interno delle politiche, sia in termini di individuazione delle sfide urbane che delle relative risposte, su due livelli. In primo luogo, saranno individuate le sfide e le risposte riferite all'adattamento all'interno dei NAP; in seguito, saranno ricercate le sfide e le risposte esplicitamente riferite ai sistemi urbani. Le sfide e le risposte possono includere la realizzazione di opere ed infrastrutture, processi di pianificazione, e questioni finanziarie (sia in termini di disponibilità che di distribuzione delle risorse finanziarie). Inoltre, sfide e risposte possono essere identificate a livello nazionale o locale all'interno di un sistema istituzionale riconosciuto'.

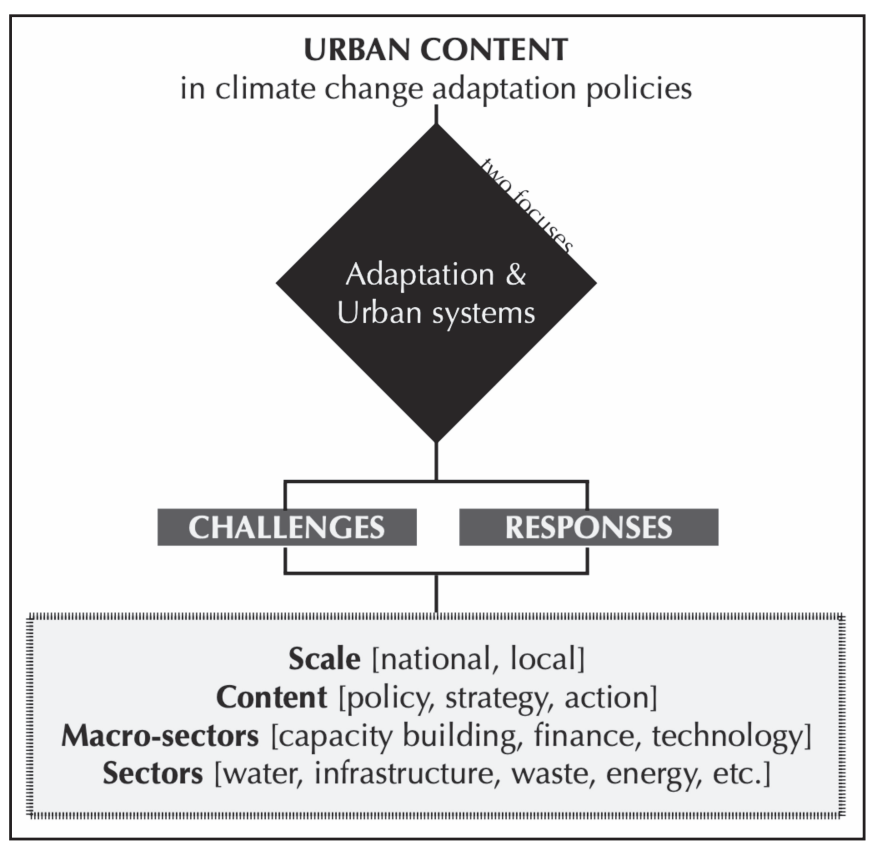

Figura 1 - Ricerca del contenuto urbano nelle politiche di adattamento al cambiamento climatico.

\footnotetext{
${ }^{1}$ Con contenuto delle politiche si fa qui riferimento a sfide o risposte frutto di principi guida forniti e approvati da un governo che ha forza di legge e che aiuta le istituzioni e le organizzazioni a prendere decisioni; inoltre, le politiche possono essere legislative (livello nazionale) o normative (livello locale). Le strategie sono definite come linee guida settoriali per raggiungere gli scopi e gli obiettivi definiti dalle politiche e strumenti per definire priorità. Le azioni offrono indicazioni specifiche che portano all'attuazione delle politiche e delle strategie, definendo i tempi, il supporto finanziario e gli sviluppi fisici.
} 
Inoltre, le sfide e le risposte sono state identificate prima sotto forma di macro-settori (adattamento, mitigazione, capacità istituzionale, tecnologia e finanziamenti), e poi in settori specifici (per esempio, gestione delle acque, infrastrutture, sicurezza alimentare). Questa ricerca ci permette di identificare i macro-settori e i settori più vulnerabili alle sfide imposte dai cambiamenti climatici in termini di adattamento, ma anche i più proattivi, resi tali dalla definizione di risposte per l'adattamento. Il paper procede poi con la valutazione e il confronto del contenuto urbano in tre politiche di adattamento che dimostrano particolare attenzione al contenuto urbano (NAP, NDCs e NUP). Infine, la ricerca si conclude individuando politiche, strategie e piani legati al clima e menzionati nei NAP al fine di evidenziare la relazione tra contenuto urbano e cambiamento climatico nei diversi riferimenti legislativi (e di pianificazione) nazionali.

La metodologia qui descritta per analizzare il contenuto urbano dei NAP deriva dalla metodologia utilizzata per la revisione del contenuto urbano dei Nationally Determined Contributions (NDCs) sviluppata da Tollin et al. (2017) e pubblicata da UN-Habitat. Gli NDCs sono presentati ogni cinque anni per definire il contributo dei Paesi nel raggiungere gli obiettivi fissati dall'Accordo di Parigi. L'applicazione della metodologia NDCs, strutturata su una matrice di indicatori, è stata condotta su 160 NDCs presentati prima dell'agosto 2016 da 188 stati (I'Europa è con- siderata come un unico caso). Tale metodologia è stata qui adattata per rispondere alle caratteristiche dei NAP, e ulteriormente ampliata per includere alcuni perfezionamenti già individuati durante l'analisi del contenuto urbano degli NDCs.

Oggetto di questo articolo è la revisione del contenuto urbano dei NAP, definite come politiche nazionali di adattamento al cambiamento climatico non vincolanti, rivolte agli Stati appartenenti al gruppo Non-Annex I definito dalI'UNFCCC (1992). I NAP possono essere adattati a tutti i contesti nazionali grazie alla flessibilità del processo che li definisce, strutturato su quattro elementi e fasi comuni: (A) definizione del contesto; (B) elementi preparatori; (C) strategie di attuazione; (D) reporting, monitoraggio e revisione (UNFCCC, 2012). Tra il 2014 e il 2020 sono stati presentati all'UNFCCC solamente 20 NAP (Figura 2), che qui costituiscono il campione della ricerca (Brasile, Burkina Faso, Camerun, Cile, Colombia, Etiopia, Fiji, Grenada, Guatemala, Kenya, Kiribati, Paraguay, Saint Lucia, Saint Vincent e Grenadine, Sri Lanka, Stato di Palestina, Sudan, Suriname, Togo, Uruguay).

La metodologia sarà testata in questo paper sul NAP del Brasile. Questo test permetterà di individuare individuato le carenze della metodologia stessa, e apportare migliorie. Successivamente al test preliminare, la metodologia sarà applicata alla revisione e all'analisi dei 20 NAP presentati prima del 31 luglio 2020, pubblicamente disponibili attraverso I'archivio online dell'UNFCCC.

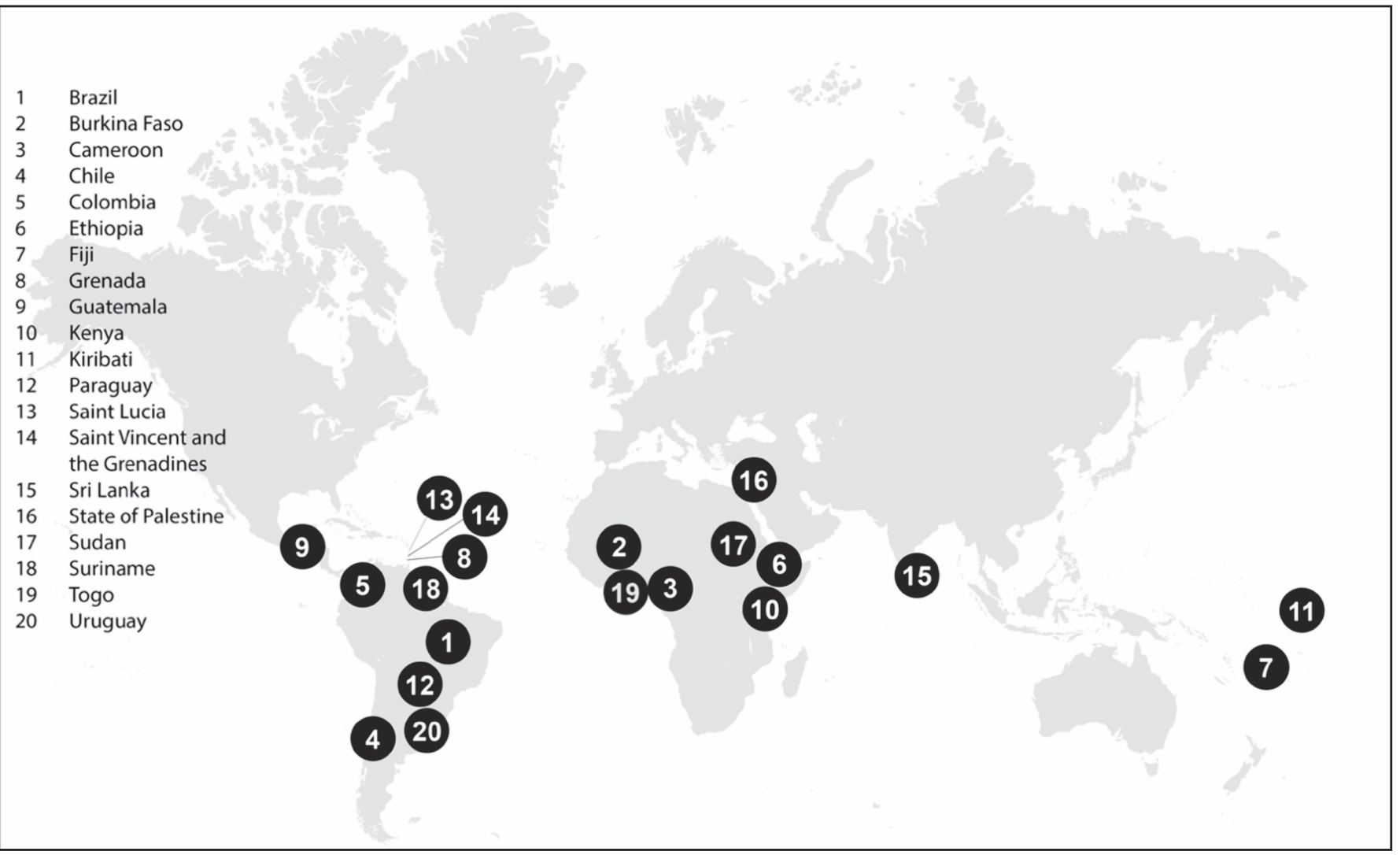

Figura 2 - Distribuzione dei 20 paesi che hanno presentato i NAP tra il 2014 e il 2020. 
La metodologia è strutturata in quattro parti (Fig. 3).

La prima è dedicata alla lettura dei NAP, alla ricerca delle sfide e delle risposte di adattamento al cambiamento climatico un particolare in relazione ai sistemi urbani e agli insediamenti umani (Fee et al., 2019).

La seconda parte è costituita dalla creazione di una matrice composta dall'incrocio di indicatori e dati dei NAP. La matrice, composta da 172 indicatori, è compilata con $\mathrm{i}$ dati ricercati all'interno dei 20 NAP, degli NDCs e dei NUP. Tale tabella è stata progettata per consentire futura aggiunta e revisione dei dati. Seguendo la metodologia degli NDCs, gli indicatori saranno accorpati in undici gruppi, seguendo quattro filoni principali: dati geografici e socioeconomici dei Paesi; dati generali e introduttivi sui NAP; informazioni sul contenuto urbano nelle politiche nazionali (NAP, NDC e NUP); link tra strumenti nazionali e internazionali e riferimenti legislativi legati al clima. Gli undici gruppi sono i seguenti:

- Indicatori geografici: Codice IOS del paese, nome del paese, nome della regione, nome della sotto-regione, reddito, lingua ufficiale.

- Indicatori generali sulla popolazione e sulle emissioni di gas serra.

- Indicatori generali dei NAP sulle sfide e le misure per I'adattamento al cambiamento climatico.

- Indicatori Urbani dei NAP: individuazione di sfide e misure urbane per l'adattamento al cambiamento climatico.

- Indicatori NDCs: priorità urbane di adattamento e mitigazione.

- Indicatori NUP: su: presenza di NUP; nome del NUP; anno del NUP; forma del NUP; fase del NUP; agenzia urbana nazionale.

- Contenuto urbano nelle politiche nazionali: contenuto urbano in NAP e NDCs.

- Collegamenti con le politiche internazionali, (inclusi SDGs, Sendai Framework for Disaster Risk Reduction, Accordo di Parigi e New Urban Agenda);

- Collegamenti nazionali tra piani/politiche/strategie/report relativi alla presenza di piano nazionale sul clima; Politica nazionale sul clima, leggi nazionali sul clima, azioni nazionali sul clima.

Questi gruppi di indicatori hanno ovviamente un peso diverso rispetto all'analisi del contenuto urbano. Gli indicatori geografici, gli indicatori generali, gli indicatori NDCs e gli indicatori NUP sono indicatori secondari che sostengono l'analisi del contesto urbano: permettono perciò di inquadrare le politiche climatiche e urbane di ogni paese, senza essere esplicitamente riferiti all'adattamento. II blocco principale è costituito dagli indicatori sui NAP e dal contenuto urbano nelle politiche nazionali (NAP, NDCs e NUP).

Nella terza parte ad ogni Paese viene assegnato un cluster rispetto alla presenza di contenuto urbano in modo tale da facilitare il confronto tra i 20 NAP analizzati. Tale risultato sarà poi confrontato con il contenuto urbano degli
NDCs per ogni Paese e con il contenuto climatico dei NUP, valutazioni sviluppate da UN-Habitat e OCSE. I cluster previsti sono:

- Cluster A: NAP con sezioni e menzioni urbane dedicate nei titoli e sottotitoli, classificati come contenuti urbani forti.

- Cluster B: NAP con menzioni urbane nel corpo del testo, classificati come contenuto urbano moderato.

- Cluster C: NAP senza menzioni urbane all'interno del testo e classificati come basso o nullo contenuto urbano.

Nella quarta parte, la metodologia affronta le relazioni tra il contenuto urbano dei NAP, i NDC e i NUP e i collegamenti tra i piani relativi al clima, le strategie, la legislazione su scala internazionale e nazionale ${ }^{2}$. I dati saranno principalmente replicati dai database delle Nazioni Unite e della Banca Mondiale; dal Report Sustainable Urbanization in the Paris Agreement, Comparative review for urban content in the Nationally Determined Contributions (NDCs) (Tollin, et al. 2017); dai NAP presentati all'UNFCCC e i database UN-Habitat; e dai database dell'OCSE³.

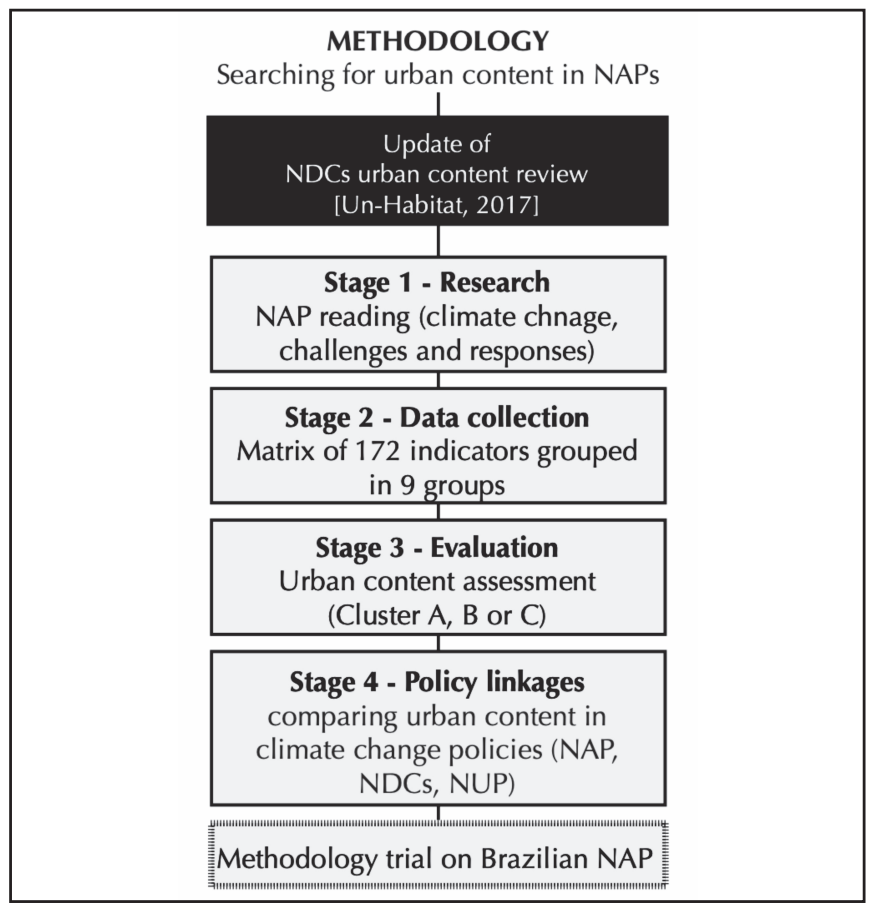

Figura 3 - La metodologia di analisi.

${ }^{2}$ Con link internazionale, si intende la menzione, all'interno del NAP, del Sendai Framework for Disaster Risk Reduction, dell'Accordo di Parigi e della New Urban Agenda. Con link nazionale, si intendono considerazioni sul clima e sulla città nelle politiche, strategie, azioni, piani o riferimenti legislativi nel contesto nazionale.

${ }^{3}$ I dati utilizzati in questa ricerca sono reperiti dai rapporti UNHabitat (2017) e OCSE (2018). Più in dettaglio, gli indici geografici e generali includono indicatori e dati raccolti dai database delle Nazioni Unite e della Banca Mondiale; gli indicatori NDCs sono tratti da Tollin et al., 2017; gli indici NAPs sono tratti dai NAP presentati dai paesi a UNFCCC e dai database UN-Habitat; gli indicatori sui NUPs sono tratti dai database di OCSE. 


\section{LA METODOLOGIA ALLA PROVA. LA VALUTAZIONE DEL CONTENUTO URBANO DEL NAP DEL BRASILE}

Per testare l'efficacia della metodologia, il paper applica la matrice degli indicatori al NAP del Brasile, in quanto il documento affronta numerose sfide imposte dal cambiamento climatico a causa della superficie estesa e della numerosa popolazione del Paese. Di seguito vengono riportati i risultati sintetici dell'analisi per ogni gruppo di indicatori.

\subsection{Indicatori geografici}

Il Brasile è il paese delle Americhe con la superficie più estesa, pari a $8.515 .767 \mathrm{kmq}$, e di conseguenza con una densità di popolazione molto bassa, pari a 25 abitanti per kmq. Rispetto alla maggior parte dei paesi appartenenti alla lista Non-Annex I, che sono caratterizzati da redditi bassi, il Brasile ha un reddito medio-alto.

\subsection{Indicatori generali}

Tre sono le dinamiche principali che emergono dall'analisi degli indicatori demografici in Brasile: (i) crescita della popolazione; (ii) elevato tasso di urbanizzazione; e (iii) elevata percentuale di popolazione che vive in insediamenti informali. II Brasile è il sesto stato più popoloso del mondo (211.049.527 abitanti, 2019). In linea con il trend di crescita della popolazione mondiale, la popolazione brasiliana è aumentata dal 2011 al 2019 del 6,85\%. Per quanto riguarda la rapida urbanizzazione, la popolazione urbana era nel 2019 l' $86,8 \%$ sul totale e dovrebbe raggiungere il $90,9 \%$ entro il 2050 . Inoltre, nel 2018 il $16 \%$ della popolazione viveva in insediamenti informali. Passando all'analisi dei dati socio-economici, il PIL pro capite del Brasile è di 15.259 dollari, l'indice di sviluppo umano (HDI) è alto, pari a 0,761 .

\subsection{Indicatori generali del NAP}

II NAP, titolato "Piano nazionale di adattamento ai cambiamenti climatici", è stato pubblicato dalla Repubblica Federativa del Brasile in collaborazione con il Ministro dell'Am-

Tabella 1 - Sintesi dell'analisi dei dati socio-economici del Brasile

\begin{tabular}{l|l} 
Continente & Americas \\
\hline \% pop. urbana (2019) & $86.8 \%$ \\
\hline \% pop. urbana (2050) & $90.9 \%$ \\
\hline Densità della pop. (2019) & 25 abitanti/km ${ }^{2}$ \\
\hline Reddito (2020) & Medio-alto \\
\hline Indice di Sviluppo Umano (2018) & Alto \\
\hline PIL pro capite \$ (2019) & 15.259
\end{tabular}

biente. È stato presentato nel 2015 e tradotto in inglese. II piano è strutturato in due volumi: il volume I, intitolato Strategia generale, contiene l'introduzione, la metodologia e l'obiettivo del piano; il volume II, intitolato Strategie settoriali e tematiche, comprende strategie approfondite riguardanti undici settori (agricoltura, biodiversità ed ecosistemi, città, gestione del rischio, industria e miniere, infrastrutture; popolazione vulnerabile, risorse idriche, salute, sicurezza alimentare e nutrizionale, zona costiera). Per ogni settore, nel NAP viene definito l'obiettivo generale, il quadro istituzionale, l'analisi qualitativa della vulnerabilità, le linee guida, le misure di adattamento per il settore e l'interdipendenza con altri settori.

Nella prospettiva di adattamento al cambiamento climatico, il piano ha elevato contenuto politico e strategico di scala nazionale. Le azioni su scala locale sono assenti. Inoltre, il NAP non menziona le perdite e i danni del mancato adattamento, né la valutazione del costo di non azione; presenta tuttavia un piano di monitoraggio e valutazione.

Nello sviluppo dell'analisi sono stati identificati due elementi, ovvero le principali sfide climatiche che rendono urgente l'adattamento a scala nazionale e le risposte identificate per I'adattamento al cambiamento climatico (Tab. 2).

Tabella 2 - NAP Brasile: sfide e risposte di adattamento

SFIDE PER L'ADATTAMENTO

\begin{tabular}{l|l}
$\begin{array}{l}\text { Cambiamento } \\
\text { climatico }\end{array}$ & $\begin{array}{l}\text { Inondazioni, siccità, eventi temporaleschi, } \\
\text { aumento delle temperature, ondate di calore, } \\
\text { degrado del territorio, intrusione di acqua sa- } \\
\text { lata, erosione costiera }\end{array}$ \\
\hline Macro-settori & $\begin{array}{l}\text { Adattamento, mitigazione, capacità istituzio- } \\
\text { nale, capacità tecnica, finanza }\end{array}$ \\
\hline Settori & $\begin{array}{l}\text { Sicurezza alimentare, biodiversità, gestione } \\
\text { delle acque, salute, industrie specifiche, mi- } \\
\text { glioramento della governance e delle infra- } \\
\text { strutture }\end{array}$ \\
RISPOSTE DI ADATTAMENTO \\
Macro-settori & $\begin{array}{l}\text { Adattamento, capacità istituzionale, capacità } \\
\text { tecnica, finanziamenti. }\end{array}$ \\
\hline Settori & $\begin{array}{l}\text { Trasporti, acqua, energia, produzione alimen- } \\
\text { tare, uso e pianificazione del territorio, indu- } \\
\text { stria, salute. }\end{array}$
\end{tabular}

In particolare, inondazioni, siccità, eventi metereologici estremi, aumento delle temperature, ondate di calore, degrado del territorio, intrusione di acqua salata, erosione costiera sono gli effetti del clima menzionati dal NAP. II Brasile è colpito da otto dei dieci impatti climatici analizzati nella metodologia, il che significa che il Paese ha un'alta vulnerabilità rispetto agli effetti del cambiamento climatico. Inoltre, il NAP identifica sfide e risposte per diversi macro-settori: adattamento, mitigazione, capacità istituzionale, capacità tecnica e la finanza (Tab. 3). L'analisi mostra che il Paese ha perciò difficoltà a mobilitare finan- 
ziamenti per rendere efficaci le strategie di adattamento. Inoltre, il piano sottolinea l'impreparazione delle istituzioni nell'affrontare il cambiamento climatico. Allo stesso tempo, per ogni strategia è definito un budget e l'istituzione responsabile della sua attuazione.

Tabella 3 - NAP Brasile: adattamento per macro-settori

\begin{tabular}{c|c|c} 
MACRO-SETTORI & SFIDE & RISPOSTE \\
Mitigazione & $\mathrm{Si}$ & $\mathrm{No}$ \\
\hline Capacità istituzionale & $\mathrm{Si}$ & $\mathrm{Si}$ \\
\hline Capacità tecnica & $\mathrm{Si}$ & $\mathrm{Si}$ \\
\hline Finanziamenti & $\mathrm{Si}$ & $\mathrm{Si}$
\end{tabular}

I settori identificati come maggiormente vulnerabili al cambiamento climatico sono la sicurezza alimentare, la biodiversità, la gestione dell'acqua, la salute, le industrie specifiche, il miglioramento della governance e le infrastrutture. Per contro, i settori in cui sono state preparate risposte di adattamento sono i trasporti, I'acqua, I'energia, la produzione alimentare, l'uso e la pianificazione del territorio, I'industria e la salute.

\subsection{Indicatori urbani dei NAP}

Gli stessi indicatori utilizzati per analizzare il contenuto di adattamento dei NAP sono stati utilizzati per indagare anche il contenuto urbano dei NAP. Partendo dai macrosettori, il NAP presenta sia sfide che misure solo per quanto riguarda la capacità istituzionale (Tab. 4).

\section{Tabella 4 - NAP Brasile: Analisi del contenuto urbano} di adattamento per macro-settori

\begin{tabular}{c|c|c}
\hline MACRO-SETTORI & SFIDE (urbane) & RISPOSTE (urbane) \\
Mitigazione & $\mathrm{Si}$ & $\mathrm{No}$ \\
\hline Capacità istituzionale & $\mathrm{Si}$ & $\mathrm{Si}$ \\
\hline Capacità tecnica & $\mathrm{No}$ & $\mathrm{No}$ \\
\hline Finanziamenti & $\mathrm{No}$ & $\mathrm{Si}$
\end{tabular}

Più in dettaglio, la vulnerabilità dei sistemi urbani è dichiarata nell'introduzione del piano e una delle 11 strategie identificate è dedicata alle città. L'analisi ha mostrato che i sistemi urbani sono principalmente colpiti da inondazioni, eventi climatici estremi e aumento della temperatura (isole di calore), nella gestione dell'uso del suolo, vulnerabilità e disastri, gestione delle acque, miglioramento della governance e delle infrastrutture. Le soluzioni si trovano principalmente in uso del suolo e pianificazione, salute e società. II contenuto urbano è più presente sotto forma di strategie in forma non molto efficace nell'implementazione delle azioni alla scala urbana.
Tabella 5 - NAP Brasile: sintesi del contenuto urbano SFIDE PER L'ADATTAMENTO

\begin{tabular}{l|l} 
Cambiamento climatico & $\begin{array}{l}\text { Inondazioni, eventi temporaleschi, } \\
\text { aumento della temperatura }\end{array}$ \\
\hline Macro-settori & $\begin{array}{l}\text { Adattamento, mitigazione, capacità } \\
\text { istituzionale }\end{array}$ \\
\hline Settori & $\begin{array}{l}\text { Gestione dell'uso del suolo e piani- } \\
\text { ficazione urbana, gestione dell'ac- } \\
\text { qua, miglioramento della gover- } \\
\text { nance e delle infrastrutture }\end{array}$
\end{tabular}

RISPOSTE DI ADATTAMENTO

\begin{tabular}{l|l} 
Macro-settori & $\begin{array}{l}\text { Adattamento, mitigazione, capacità } \\
\text { istituzionale }\end{array}$ \\
\hline Settori & $\begin{array}{l}\text { Uso e pianificazione del territorio, } \\
\text { salute, società }\end{array}$
\end{tabular}

\subsection{Indicatori NDCs}

Nel 2015, la Repubblica Federativa del Brasile ha comunicato al UNFCCC il proprio NDC con l'obiettivo di ridurre nel 2025le emissioni di gas serra del $37 \%$ rispetto ai livelli del 2005. La revisione del contenuto urbano dell'NDC evidenzia che la politica brasiliana ha identificato priorità di adattamento urbano ma non di mitigazione (Tollin et al. 2017). Nella revisione, le priorità di mitigazione si riferiscono a priorità non necessariamente urbane ma rilevanti per i sistemi urbani, con riferimento a energia, trasporti, edilizia, rifiuti, acqua, efficienza industriale, riduzione dei gas serra e rafforzamento della governance. Invece, le priorità di adattamento si riferiscono a priorità generiche non necessariamente legate al sistema urbano, e comprendono la sicurezza alimentare, la gestione e l'uso uso del territorio, la vulnerabilità e i disastri, la conservazione della biodiversità e/o degli ecosistemi, la gestione delle acque, la salute/assistenza sanitaria, I'industria specifica e il miglioramento della governance.

\subsection{Indicatore NUPs}

Il ruolo della Politica Urbana Nazionale (NUP) è stato stabilito durante la United National Conference on Housing and Sustainable Urban Development (Habitat III), Quito 2016. Il documento finale della conferenza è stato la New Urban Agenda (NUA), un documento orientato all'azione per guidare lo sviluppo urbano sostenibile a livello locale (NUA, 2016), che identifica la NUP come uno degli elementi chiave per raggiungere lo sviluppo e la crescita sostenibile (OECD, 2018). Come riportato nel Rapporto OCSE (2018), il NUP brasiliano, intitolato "Statuto della città", è stato presentato nel 2002 dal Consiglio Nazionale dello Sviluppo; tuttavia non sono state fornite informazioni sulla forma e sulla fase del NUP.

\subsection{Contenuto urbano nelle politiche nazionali}

I dati sugli impatti del cambiamento climatico e le sfide e le risposte di adattamento identificate finora hanno per- 
messo di assegnare il cluster di contenuto urbano al NAP del Brasile. Il risultato è che in Brasile il NAP ha il cluster urbano A (forte) poiché ha identificato le priorità urbane di adattamento e mitigazione e risposte di solamente per I'adattamento, tra cui "I'attuazione di politiche pubbliche per lo sviluppo urbano che combinano la pianificazione urbana e la gestione del rischio in una prospettiva di prevenzione" (Federative Republic of Brazil, 2016, p.58). Questo risultato è stato confrontato con il contenuto urbano identificato nel NDCs del Brasile da UN-Habitat (2017), che mostra che il NDCs ha il cluster B (moderato), e che ha identificato solo priorità di adattamento urbano. II contenuto urbano del NUP non è stato classificato.

\subsection{Collegamenti politici internazionali}

Nel NAP, il Brasile considera e menziona l'Accordo di Parigi (2015) e il Sendai Framework per la riduzione del rischio di disastri. II NAP non menziona gli SDGs.

\subsection{Collegamenti tra piani nazionali/politiche/strategie/rapporti}

Infine, si è ricercato quali politiche, piani e strategie brasiliane relative al clima fossero menzionate nel testo del NAP (per esempio, piano o strategia nazionale sul clima). L'analisi del NAP mostra che il Brasile ha adottato: Piano Nazionale per il Cambiamento Climatico; Politica Nazionale per il Cambiamento Climatico (PNMC - Legge 12.187/09) e il suo decreto di attuazione (Decreto 7.390/10); Panel Brasiliano sul Cambiamento Climatico (PBMC); e Politica Nazionale di Protezione e Difesa Civile, istituita dalla Legge 12.608, del 10 aprile 2012.

\section{CONCLUSIONI. PROPOSTE DI LAVORO PER LA VALU- TAZIONE DEL CONTENUTO URBANO NELLE POLITICHE DI ADATTAMENTO AL CAMBIAMENTO CLIMATICO}

Dal test condotto sul Brasile, è possibile affermare che la metodologia illustrata nell'articolo è funzionale all'assegnazione del cluster urbano al NAP e all'identificazione di sfide e risposte sia per l'adattamento che per il contenuto urbano. Il punto di forza della metodologia è la possibilità di continuo aggiornamento: la metodologia può essere sviluppata e adattata sulla base delle priorità emergenti dai futuri NAP e su altre questioni che emergono dalla letteratura scientifica e grigia. La metodologia può essere ripetuta, modificata e utilizzata per diversi scopi: ad esempio, può essere usata per analizzare altre politiche legate al clima riguardanti il contenuto urbano o per ricercare altri settori o temi all'interno dei NAP, come I'uso dell'acqua o dell'energia. Tuttavia, I'analisi della metodologia ha evidenziato alcune debolezze e possibili miglioramenti, che verranno illustrati di seguito a partire dalla struttura dei nove gruppi di indicatori analizzati.

Partendo dagli indicatori geografici, un'analisi di contesto più approfondita aiuterebbe a capire la condizione che caratterizza ogni Paese, permettendo una migliore analisi delle vulnerabilità territoriali. Sarebbe necessario introdurre indicatori sulla morfologia, idrografia, suoli, flora e fauna. Per fornire alcuni esempi riferiti alla scala nazionale e al momento della redazione del NAP, conoscere la morfologia di un'area porterebbe all'identificazione delle zone più vulnerabili del territorio, quelle maggiormente esposte agli impatti del cambiamento climatico, quali erosione delle coste e aumento delle inondazioni. Inoltre, lo studio del clima permetterebbe di prevedere i picchi di temperatura, mentre lo studio della composizione dei suoli permetterebbe di studiare l'erosione del suolo. Infine, uno studio idrografico identificherebbe le vulnerabilità relative ai grandi corsi d'acqua o al mare. Queste analisi dovrebbero essere ricondotte ai principali effetti del cambiamento climatico identificati nei NAP.

Passando agli indicatori generali, per renderli di più facile lettura e analisi, sarebbe necessario confrontare i dati nazionali con quelli continentali. La categorizzazione del reddito, la percentuale della popolazione, I'aumento della popolazione urbana, la percentuale della popolazione che vive negli slum, la densità della popolazione, il prodotto interno lordo (PIL) pro capite e l'indice di sviluppo umano (HDI) dovrebbero essere riportati su scala continentale per avere un target di riferimento. Questa considerazione è ancora più necessaria data la dispersione geografica dei 20 stati che hanno presentato i NAP tra il 2014 e il 2020. Inoltre, sarebbe utile aggiungere indicatori sull'età della popolazione, che permetterebbero di considerare i segmenti vulnerabili della popolazione oltre che il livello di istruzione in termini di alfabetizzazione.

Guardando agli indicatori generali dei NAP, il titolo, la data, la lingua, il proponente, il contenuto, la scala e la tempistica sono considerati informazioni sufficienti per fornire un'introduzione al NAP. Altri indicatori possono essere combinati, per esempio, aggiungendo i settori esplorati nella politica, come l'acqua, I'agricoltura, la silvicoltura, i rifiuti, la salute, soprattutto se la metodologia è usata, come in questo caso, per cercare contenuti specifici (per esempio, il contenuto urbano). La valutazione delle sfide e delle risposte di adattamento dovrebbe essere utilizzata per definire nuove linee guida del processo dei NAP in un processo continuo e circolare.

Per quanto riguarda gli indicatori urbani dei NAP, i risultati delle sfide e delle risposte di adattamento alla scala urbana possono essere utilizzati nello sviluppo di nuove linee guida UN-Habitat per rafforzare il contenuto urbano nei NAP. Un indicatore specifico sulle città potrebbe essere aggiunto nella metodologia al fine di identificare più facilmente le città con le maggiori debolezze o opportunità di adattamento al cambiamento climatico.

Analizzando gli indicatori degli NDCs, dall'analisi del contenuto urbano degli NDCs del 2017 emerge il cluster del contenuto urbano e la presenza di priorità di adattamento e/o mitigazione. I risultati dell'analisi dovrebbero rendere esplicito se gli NDCs hanno identificato risposte e azioni di adattamento e mitigazione. I risultati degli NDC sono 
principalmente riportati su scala continentale: sarebbe interessante costruire più schede nazionali che permettano una più comoda lettura e comprensione dei risultati.

Per quanto riguarda gli indicatori NUP, la revisione delI'OCSE e di UN-Habitat (2018) si configurava come un'analisi dello stato di avanzamento dei NUP. Poiché le NUP per definizione sono politiche urbane, la metodologia potrebbe essere utilizzata per ricercare il contenuto climatico al loro interno. Gli indicatori dovrebbero essere tradotti dall'adattamento al clima. Inoltre, i cluster potrebbero sempre essere utilizzati per definire il livello di contenuto climatico: forte (cluster A), moderato (cluster B), basso o nullo (cluster C).

Confrontare il contenuto urbano in diverse politiche a livello nazionale, come in NAP e NDC, è utile sia per UNHabitat, per capire come migliorare le linee guida per rafforzare il contenuto urbano nelle politiche climatiche, sia per gli Stati che sono in grado di capire se hanno integrato efficacemente il contenuto urbano e per condividere esperienze e buone pratiche. II confronto dovrebbe essere esteso ad altre politiche, strategie e piani climatici per avere un quadro climatico completo per ogni nazione.

Per quanto riguarda i link con le politiche internazionali, è stato dichiarato che la metodologia riporta solo le politiche e gli accordi internazionali menzionati nei NAP. Per quanto riguarda l'analisi del contenuto urbano, sarebbe opportuno studiare le politiche adottate in ogni nazione per definire se e come il contenuto urbano è stato considerato, e se in maniera integrata o frammentata.
L'ultimo gruppo di indicatori, che comprende i link tra piani/politiche/strategie/relazioni nazionali, contiene solo le politiche, le strategie, i piani e i riferimenti legislativi relativi al clima menzionati all'interno del NAP. Questa analisi presenta, finora, alcune criticità perché, per esempio, ogni Paese nomina le sue politiche climatiche in modo diverso, rendendo difficile anche solo trovare le politiche per ogni Stato. Inoltre, sono molto differenziate nel contenuto e nella struttura. Sarebbe necessario proporre delle linee guida internazionali per la loro formazione per poter più facilmente confrontare i risultati e scambiare buone pratiche tra i paesi. Sarebbe quindi necessario identificare tutte le politiche, le strategie e i riferimenti legislativi relativi al clima sviluppati su scala nazionale indagando il loro contenuto urbano: questo permetterebbe di avere un quadro integrato delle politiche climatiche su scala nazionale.

In altre parole, per rendere la revisione del contenuto urbano del NAP uno strumento funzionale ai governi nazionali e locali per implementare le azioni sul clima, la metodologia dovrebbe essere replicata in tutti i Paesi che hanno presentato i NAP fino ad oggi. La revisione del contenuto urbano aiuterebbe Un-Habitat a definire un focus più forte sull'implementazione dell'azione per il clima alI'interno delle nuove linee guida che rafforzano il contenuto urbano nei NAP. In secondo luogo, permetterebbe alle nazioni di capire i limiti o i punti di forza delle loro politiche, confrontando anche i loro risultati con quelli di altri paesi. In estrema sintesi è questa la potenzialità della metodologia che qui è stata proposta e descritta.

* Maria Pizzorni, University of Southern Denmark. Civil and Architectural Engineering Department, Odense, Danimarca e-mail: mpiz@iti.sdu.dk

** Ombretta Caldarice, Politecnico di Torino. Responsible Risk Resilience Centre. Dipartimento Interateneo di Scienze, Progetto e Politiche del Territorio, Torino, Italia e-mail: ombretta.caldarice@polito.it

*** Nicola Tollin, University of Southern Denmark. Civil and Architectural Engineering Department, Odense, Danimarca e-mail: nto@iti.sdu.dk

Contributo degli autori

Questo articolo è il risultato dell'attività di ricerca combinata degli autori. Tuttavia, Maria Pizzorni è autrice della versione finale del paragrafo 3; Ombretta Caldarice è autrice della versione finale del paragrafo 1, Nicola Tollin è autore della versione finale dei paragrafi 2 e 4 .

\section{Bibliografia}

AYLETT A., Institutionalizing the urban governance of climate change adaptation: Results of an international survey, Urban Climate, Vol. 14, 2015, pp. 4-16.

DOI:https://doi.org/10.1016/j.uclim.2015.06.005

Berrang-Ford L., Ford J.D., Paterson J., Are we adapting to climate change?, Global Environmental Change, Vol. 21(1), 2011, pp. 25-33.

DOI:https://doi.org/10.1016/j.gloenvcha.2010.09.012.

BerRANG-Ford L., FORD J.D., LeSNIKOWSKI A. et al., What drives national adaptation? A global assessment, Climatic Change, 2014.

DOI: 10.1007/s10584-014-1078-3. 
Brunetta G., Caldarice O., Tollin N. et al., Urban Resilience for Risk and Adaptation Governance. Theory and Practice, Springer International Publishing, 2019.

DOI: 10.1007/978-3-319-76944-8.

Carmin J.A., Anguelovski I., Roberts D., Urban climate adaptation in the global south: Planning in an emerging policy domain, Journal of Planning Education and Research, 2012.

DOI: 10.1177/0739456X11430951.

Datta A., Shaban A., Mega-Urbanization in the Global South: Fast Cities and New Urban Utopias of the Postcolonial State, 2016.

DOI: $10.4324 / 9781315797830$.

Evans J.P., Resilience, ecology and adaptation in the experimental city, Transactions of the Institute of British Geographers, 2011.

DOI: 10.1111/j.1475-5661.2010.00420.x.

Federative Republic Of Brazil, National Adaptation Plan to Climate Change, 2017.

Fee L., Mayr M., Wang Y. et al., Addressing Urban and Human Settlement Issues in National Adaptation Plans: A Supplement to the UNFCCC Technical Guidelines on the National Adaptation Plan Process, Nairobi, 2019 (downloadable from the website: https://www4. unfccc.int/sites/NAPC/Documents/Supplements/NAP-Hu man Settlement.pdf).

Hallegatte S. And Corfee-Morlot J., Understanding climate change impacts, vulnerability and adaptation at city scale: An introduction, Climatic Change, 2011.

DOI: 10.1007/s10584-010-9981-8.

HaRMAN B.P., TAYlOR B.M., LANE M.B., Urban partnerships and climate adaptation: challenges and opportunities, Current Opinion in Environmental Sustainability, Vol. 12, pp. 74-79.

DOI: https://doi.org/10.1016/j.cosust.2014.11.001.

Masson V., Marchadier C., Adolphe L. et al., Adapting cities to climate change: A systemic modelling approach, Urban Climate, 2014.

DOI: 10.1016/j.uclim.2014.03.004.

Matthews T., Climate Change Adaptation in Urban Systems: Strategies for Planning Regimes, Program, 2011.

MeERow S., Newell J.P., Urban resilience for whom, what, when, where, and why?, Urban Geography, Vol 40(3), 2019. DOI: 10.1080/02723638.2016.1206395.

Meerow S., Newell J.P., Stults M., Defining urban resilience: A review. Landscape and Urban Planning, Vol. 147, 2016, pp. 38-49.

DOI:https://doi.org/10.1016/j.landurbplan.2015.11.011.

OECD, Global State of National Urban Policy. Global State of National Urban Policy, 2018.

DOI: 10.1787/9789264290747-en.
Olazabal M., Ruiz De Gopegui M., Adaptation planning in large cities is unlikely to be effective, Landscape and Urban Planning, 2021.

DOI: 10.1016/j.landurbplan.2020.103974.

Plescia-Boyd A., Un-Habitat et al., Enhancing Nationally Determined Contributions through Urban Climate Action, Nairobi, 2020. Available at: https://unhabitat. org/sites/default/files/2020/06/ndc_guide_19062020.pdf.

Prieur-Richard A.-H., Walsh B., Craig M. et al. Global Research and Action Agenda on Cities and Climate Change Science, 2018 (downloadable from the website:https://www.ipcc.ch/site/assets/uploads/2019/07/ Research-Agenda-Aug-10_Final_Short-version.pdf).

Romero LankaO P., QIN H., Conceptualizing urban vulnerability to global climate and environmental change. Current Opinion in Environmental Sustainability, Vol. 3(3), 2011, pp. 142-149.

DOI: 10.1016/j.cosust.2010.12.016.

SIMON D., New evidence and thinking on urban environmental change challenges, International Development Planning Review, 2014.

DOI: $10.3828 /$ idpr.2014.9.

Tollin N., Hamhaber J., Grafakos S. et al. Sustainable Urbanization in the Paris Agreement. Comparative review for urban content in the Nationally Determined Contributions (NDCs), United Nations Human Settlements Programme (UN-Habitat), 2017 (downloadable from the website:https://unhabitat. org/sites/default/files/download-manager-files/Paris Agre ement_25_Jan-2019_for Email-Online.pdf).

UNFCCC, United Nations Framework Convention, 1992 (downloadable from the website: https://unfccc.int/ resource/docs/convkp/conveng.pdf).

UNFCCC, National adaptation plans: Technical guidelines for the national adaptation plan process, Least Developed Countries Expert Group, 2012.

UNFCCC, Nationally determined contributions under the Paris Agreement. Synthesis report by the secretariat, 2021 (downloadable from the website:http://unfccc. int/resource/docs/2009/cop15/eng/11a01.pdf).

UNITED NATIONS, Paris Agreement - UNFCCC. Conference of the Parties on its twenty-first session, 2015. DOI: 10.1017/S0020782900004253.

Vincent K., Cundill G., The evolution of empirical adaptation research in the global South from 2010 to 2020, Climate and Development, 2021.

DOI: 10.1080/17565529.2021.1877104.

Williams B., Statement of Climate Change. Un Habitat. Nairobi, Kenya, 2007 (downloadable from the website: https://sustainabledevelopment.un.org/content/docume nts/habitat_2may_cc.pdf). 